\title{
1 Maize leaf functional responses to drought episode and rewatering
}

2

4

He Song ${ }^{1,2}$, Yibo $\mathrm{Li}^{1,2}, \mathrm{Li}_{\text {Zhou }}{ }^{3}$, Zhenzhu Xu ${ }^{1}$, Guangsheng Zhou ${ }^{1,3}$

${ }^{1}$ State Key Laboratory of Vegetation and Environmental Change, Institute of Botany, Chinese Academy of Sciences, Beijing 100093, China; ${ }^{2}$ Graduate School of Chinese Academy of Sciences, Beijing 100049, China; ${ }^{3}$ Chinese Academy of Meteorological Sciences, China Meteorological Administration, Beijing 100081, China

*Corresponding authors: xuzz@ibcas.ac.cn, gszhou@ibcas.ac.cn

\section{Abstract}

Effects of crop growth and physiological activity to drought and irrigation regimes have been extensively studied; however, the responses of plant growth, morphological and photosynthetic behaviors to drought episodes and thereafter rewatering receive a less attention. This field experiment was carried out directly in situ at an agricultural ecosystem research station during 2015-2016, in a northeastern China, on the renowned northeastern maize production belt, where is being threatened by severe drought. A field automatic rain-shelter was used, and five irrigation regimes including control, four drought episodes, and rewatering treatments were established. The chlorophyll contents (SPAD values), light-saturated photosynthetic rate $\left(A_{\text {sat }}\right)$, and photosystem II actual quantum yield $\left(\Phi_{\mathrm{PSII}}\right)$, maximum quantum yield $\left(F_{\mathrm{v}}{ }^{\prime} / F_{\mathrm{m}}{ }^{\prime}\right)$ decreased at lower leaf positions and with plant development. Episodic drought effects on plant growth, leaf morphological traits and photosynthetic processes at both vegetative and reproductive stages were severely remarked, particularly at late development stage and with longer drought duration. The recovery of leaf functional traits of the plants experienced historical-drought following re-irrigating was not fully restored to the level of the plants subjected to ample and normal water status; and the strength of recovery was proportional to the persistence of pre-drought episodes. The relationship of $A_{\text {sat }}$ with SPAD depends on water status and plant development. A principal component analysis can well denote the change patterns in responses to water status treatments with plant development. The results may give an insight into 
how to understand the maize traits' responses to drought episode and rewatering, and this also might assist the drought-stricken crops to cope with future climatic change. Kew Words: Climate Change; Drought Episode; Irrigation Regimes; Leaf Age; Photosynthetic Potentials; Zea Mays L.

\section{Introduction}

Climate change results in abnormal changes in precipitation patterns in terms of both its total amounts and episodic drought frequencies (Alley et al. 2003; Trenberth et al. 2014; IPCC 2014). Water shortage is a crucial constraint to crop growth, yield, physiological processes in many areas around world, including rain-fed and deficit-irrigation regions; meanwhile the abnormal occurrences of drought episodes usually fluctuates at various spatial-temporal scales (Boyer 1982; Battisti \& Naylor 2009; IPCC 2014; Rurinda et al. 2014; Myers et al. 2017). Intensifying drought also may eliminate the expected benefits from some fewer favorite factors due to climate change such as elevated $\mathrm{CO}_{2}$ and enhanced anthropogenic nitrogen (N) deposit (Iversen \& Norby 2014; Gray et al. 2016; Xu et al. 2016), and climatic warming may exacerbate drought disaster by further reducing soil moisture availability (Zeng et al. 2005; Lobell et al. 2011, 2014; Iversen \& Norby 2014). As reported, due to potentially adverse climate change, since1950s to the present, agricultural drought-inducible disaster area also had an increasing trend in China-the drought-induced grain loss reached approximate 25-30 billion $\mathrm{kg}$, accounting for $60 \%$ of total loss of natural disaster (Jiao et al. 2014, Zhou 2015). It has been notable that China's agricultural drought becomes more serious mainly due to the adverse climate change and rapid social-economic development.

Maize is one of the most important three staple crops-maize, wheat, and rice, and the main resources of the feed, industrial raw materials (Campos et al. 2004; Long et al. 2006; Ribaut et al. 2009), recent years it ranked first place among the three staple crops (FAO 2017). In China, it also plays a critical role in food security and husbandry industry development among agricultural and even entire economic sectors 
at both regional and national levels (Meng et al. 2013; Ma \& Ma 2017; PINC 2017). Drought is one of major limitations to maize production (Boyer 1982; Sharp et al. 2004; Xu et al. 2008; Lobell et al. 2014; Avramova et al. 2015), resulting in a yield reduction of $25-30 \%$, even with no harvest in those years of extremely severe drought (Campos et al. 2004; Zhang et al. 2011). In USA major maize production zone, the drought sensitivity in maize production in recent two decades has been also reported to increase, despite cultivar improvements and the agronomic practices with higher sowing densities (Lobell et al. 2014). Climatic warming is projected to further exaggerate drought's negative impact, leading to huge loss of maize production (Ribaut et al. 2009; Lobell et al. 2014). Drought stress leads to reductions in maize (Zea mays L.) and other crops' yields mainly by (i) reducing plant growth and reproductive activities, (ii) reducing photosynthetic potentials and thereby radiation use efficiency (RUE), and (iii) reducing harvest index (HI) (Saini \& Westgate 1999; Earl \& Davis 2003; Barnabás et al. 2008; Xu et al. 2008). Contrastingly, if a maize cultivar root system and its ear growth are not completely limited, and leaf survival is enhanced despite water deficit, the cultivar may be recognized as high drought-tolerant one (Ribaut et al. 2009). Nevertheless, the intermittent drought imposition, and then following rewatering effects on crop plants grown in field still receive a relatively scant attention.

Based on cyclic drought experiment using Catalpa bungei species, the accumulative functional effects of progressive drought and subsequent re-watering on plant growth, leaf and root parameters has been found as a useful adaptive mechanism to drought successive drought and subsequent rewatering (Zheng et al. 2017). As recently reported by Abid et al. (2016), the adaptability to drought, and recovery rate and capacity was closely associated with wheat cultivars. The accumulation of effective metabolites such as sugars, and some amino acids like proline and leucine may exert an adaptive mechanism in response to the drought cyclic patterns (Meyer et al. 2014; Foster et al. 2015; Sun et al. 2016; Zheng et al. 2017). In plants of Lupinus albus, the new leaves can be produced more as quickly re-watered, although 
restoration of other metabolites (e.g. sugar content) was lagged (Pinheriro et al. 2004).

Maize leaf length undergone one or several days of drought can restore completely following rewatering, but its growth rate could not reach the control level, suggesting that the growth resumption may be only a postponed event, no overcompensation occurrence (Acevedo et al. 1971). It is implied that the magnitude and rate of resumption might depend on pre-drought intensity and its duration (Hsiao 1973; Xu \& Zhou 2007; Xu et al. 2009, 2010). Thus, the extent of compensation for the limitation of pre-drought by promoting plant growth as rewatering might determine the final plant biomass or crop yield, which may link to drought severity and its duration. Nevertheless, whether plant growth and physiological activities completely recovery following rewatering, what are the rate and degree of recovery, and the ability of the adaption to the drying-rewetting cycles might strongly depend on previous drought strength and persistent duration, species and genetic types, and drying-rewetting cycle patterns, which the underlying mechanism is elusive so far (Loewenstein \& Pallardy 2002; Marron et al. 2003; Flexas et al. 2004; Yahdjian \& Sala 2006; Xu et al. 2009, 2010; Sun et al. 2016; Zheng et al. 2017). Thus, responses of plant growth and leaf functional processes to drought history and subsequent rewatering remain to be clarified further, particularly in situ crop field.

As stated above, drought effects on plant/crop growth, photosynthesis, and other crucial eco-physiological process have been investigated extensively (e.g., Ne Smith \& Ritchie 1992; Yordanov et al. 2002; Chaves et al. 2002; Harrison et al. 2014). However, as just recently stated by Abid et al. (2016), "studying plants' capability to adapt and recover from drought stress is essential because of the ever-changing nature of drought events". Herein, the objectives of this present study were to: (1) examine the effects of drought episode and rewatering on photosynthetic capacity and chlorophyll fluorescence; (2) compare the leaf functional responses to drought episode and rewatering at different leaf positions from bottom-most to upmost leaves, at various plant growth developments; (3) determine changing patterns in responses to drought episode and recovery after re-watering on photosynthetic capacity and chlorophyll fluorescence with the leaf developments; and (4) elucidate the index for 
119 drought adaptability and recovery ability following a pre-drought episode. Our 120 hypotheses are expected: i) drought-episode-induced negative responses may depend 121 on leaf ages/positions and leaf/plant development; ii) the amelioration of 122 drought-induced negative responses by rewatering in field grown maize plants may 123 mainly result from gas exchange behaviors relative to the chlorophyll fluorescence performances-photosystem II (PSII) photochemical processes; iii) the morphological and physiological functional traits may closely interacted, coordinately representing the adaptive responses to episodic drought and following re-wetting.

\section{Materials and Methods}

129

130

131

132

133

\subsection{Site descriptions}

The present two-year field experiment was carried out directly in situ at an agricultural ecosystem research station during $2015-2016\left(41^{\circ} 49 \mathrm{~N}, 121^{\circ} 12^{`} \mathrm{E}, 27.4 \mathrm{~m}\right.$ a.s.1.), Jinzhou Ecology and Agricultural Meteorology Center, Jinzhou, Liaoning, a northeastern Chinese province on the renowned northeastern maize production belt (PINC 2017). This region is located in the northeast of the Eurasian areas, belongs to the warm temperate semi-humid monsoon climate, and atmospheric circulation mainly composed of westerlies and subtropical systems, with clear four seasons. The mean annual temperature is $7.8-9.0{ }^{\circ} \mathrm{C}$, with the extreme maximum temperature of $41.8{ }^{\circ} \mathrm{C}$ and the extreme minimum temperature of $-31.3{ }^{\circ} \mathrm{C}$; annual frost-free period is 144-180 days; average annual rainfall is $540-640 \mathrm{~mm}$, with $60 \%-70 \%$ of rainfall concentrated in the summer. The soil is the typical brown soil, with a soil $\mathrm{pH}$ value of 6.3. The organic matter and total nitrogen content is $6.41-9.43 \mathrm{~g} \mathrm{~kg}^{-1}$ and $0.69 \mathrm{~g} \mathrm{~kg}^{-1}$, respectively. The staple crop in the region is maize (Han et al. 2007).

\subsection{Experimental design}

This study, a maize water-controlled field experiment, was conducted using a huge mobile rain-proof shelter during two growth seasons of 2015-2016. The two-year experimental design and its results were similar; thus, here the 2016-year results were 
mainly reported (for 2015-year experimental design and its results, see the Supporting Information File: Table S1 \& S2, and Figures S1-S3). In the 2016-year experiment, the five irrigation treatments were designed: $T_{1}, T_{2}, T_{3}, T_{4}$, and $T_{5}$ treatments, which denote Control, withholding water during jointing-tasseling, jointing-anthesis, tasseling-milking, and silking-milking, with 260, 188, 138, 136, and $161 \mathrm{~mm}$ irrigation amount in entire developmental stage, respectively (Table 1).

There were three replicates in each treatment and 15 plots in total. Each plot is $5 \mathrm{~m}$ long and $3 \mathrm{~m}$ wide, surrounded by cement layer to avoid water permeation. The large mobile water-proof shelter is $4 \mathrm{~m}$ high, which is used for simulated precipitation to avoid the rainfall entrance. Maize cultivar used in this experiment was Danyu 405, which has been planted widely in this region. Seeds were sowed on 23 May, 2016. Controlled release fertilizer was used with $600 \mathrm{~kg} \mathrm{~km}^{-2}$.

\subsection{Environmental variables and maize traits measurements}

Soil relative water content (SRWC) measurements We used weighing method to measure the soil relative water content. Methods with soil auger were used to retrieve soil samples $(0-50 \mathrm{~cm})$, then put the samples to the aluminum specimen box, and weighed the samples to obtain the wet weight. Later, the samples were dried in an oven at $105{ }^{\circ} \mathrm{C}$ until a constant weight, and then the dried soil sample was weighed. There were three replicates in each treatment. The SRWC was calculated by the equation below:

SRWC $=($ Wet soil weight - Dry soil weight $) /$ Dry soil weight $/$ F.C. $\times 100 \%$ where F.C. is the soil water content measured $24 \mathrm{~h}$ after amply wetting the soil.

Chlorophyll content measurements The relative chlorophyll contents (i.e., SPAD values) of maize leaves were measured by a SPAD-502 meter (Minolta Camera Co. Ltd., Japan). We chose 3-5 plants grown healthily for each treatment, and each leaf was measured three times on the leaf middle area to avoid the main vein, and then averaged. 
178 Photosynthetic and chlorophyll fluorescence parameters When measured the 179 photosynthetic parameters, three-five plants grown healthily were chosen for each 180 treatment, with a CIRAS-2 gas exchange system (PP Systems, Hertfordshire, UK). We measured the upper (i.e., the youngest and expanded leaves, 1-2 leaves from the top of the plants), middle (ear leaf or the leaves above or below ear leaf) and lower positions (relative orderly leaves) of each plant, respectively. Instrumentation system provided the red and blue built-in light source, and light intensity (Photosynthetically active radiation, PAR) was set to $1500 \mu \mathrm{mol} \mathrm{m}^{-2} \mathrm{~s}^{-1}$. To ensure ample temperature and humidity conditions, the photosynthetic parameters of the maize leaves were measured at 9:00-11:00. The whole measuring process was used an open gas path, air relative humidity was controlled in $50 \%-70 \%, \mathrm{CO}_{2}$ concentration was controlled in $380-390 \mu \mathrm{mol} \mathrm{mol}{ }^{-1}$, and leaf temperature was set up at around $27{ }^{\circ} \mathrm{C}$. The parameters included light-saturated net photosynthetic rate $\left(A_{\text {sat }}\right)$, transpiration rate $(E)$, stomatal conductance $\left(g_{\mathrm{s}}\right)$; and the leaf water use efficiency (WUE) was calculated by the formula: $\mathrm{WUE}=A_{\mathrm{sat}} / E$.

The chlorophyll fluorescence parameters were measured using a chlorophyll fluorescence module (CFM) integrated with the CIRAS-2 gas exchange system at the same part of the same leaves measured simultaneously for the gas exchange parameters. First, the leaves were lighted at a light intensity of $1500 \mu \mathrm{mol} \mathrm{m} \mathrm{m}^{-2} \mathrm{~s}^{-1}$ after 15 min to measure the steady-state fluorescence $\left(F_{\mathrm{s}}\right)$, and then gave a strong flash $\left(5100 \mu \mathrm{mol} \mathrm{m} \mathrm{m}^{-2}\right.$, with pulse time of $\left.0.3 \mathrm{~s}\right)$ to measure the maximum fluorescence $\left(F_{\mathrm{m}}\right)$; later put the leaves under dark adaptation for $3 \mathrm{~s}$, opened the far red after $5 \mathrm{~s}$ to measure the minimum light fluorescence $\left(F_{\mathrm{o}}{ }^{\prime}\right)$. According to the expressions, we calculated chlorophyll fluorescence parameters: maximum quantum yield of PSII photochemistry $\left(F_{\mathrm{v}}{ }^{\prime} / F_{\mathrm{m}}{ }^{\prime}\right)$, quantum yield of PSII electron transport $\left(\Phi_{\mathrm{PSII}}\right)$, photochemical quenching ( $\left.\mathrm{q}_{\mathrm{P}}\right)$, and non-photochemical quenching (NPQ) (Genty et al.

$$
F_{\mathrm{v}}{ }^{\prime} / F_{\mathrm{m}}{ }^{\prime}=\left(F_{\mathrm{m}}{ }^{\prime}-F_{\mathrm{o}}{ }^{\prime}\right) / F_{\mathrm{m}}{ }^{\prime}
$$

$$
\Phi_{\mathrm{PSII}}=\left(F_{\mathrm{m}}{ }^{\prime}-F_{\mathrm{s}}\right) / F_{\mathrm{m}}{ }^{\prime}
$$




$$
\mathrm{q}_{\mathrm{P}}=\left(F_{\mathrm{m}}{ }^{\prime}-F_{\mathrm{s}}\right) /\left(F_{\mathrm{m}}{ }^{\prime}-F_{\mathrm{o}}{ }^{\prime}\right)
$$

$$
\mathrm{NPQ}=\left(F_{\mathrm{m}}-F_{\mathrm{m}}{ }^{\prime}\right) / \mathrm{F}_{\mathrm{m}}{ }^{\prime}
$$

Plant height and leaf area measurements Plant height and leaf area of maize were measured at different stages, and the measured dates were approximately consistent with those for the measurements of photosynthetic and fluorescence parameters. Maximum length and width were measured for ech leaf of a maize plant. A conventional formula of the total leaf area per plant was used (Francis et al. 1969):

Total leaf area of an entire plant $=\sum_{i=1}^{n}(L i \times W i \times 0.75)$

where $i$ is the leaf order number of the measured plant, $n$ is total number of the plant, $L i$ is leaf maximum, and Wi leaf maximum width.

\section{Leaf rolling index, leaf erection index, and leaf drooping angle determinations}

The upper leaf actual width (at natural state, Ln), maximum width (at unfolding state, Lw), natural length (Lnl), maximum length (Lsl), basic angle of leaf (the angle between leaf and stem), drooping angle (under the naturally bending down of the leaf, the angle between the line from the pulvinus to the tip and the stem) were determined. Then, the leaf rolling index (LRI, \%), leaf erection index (LEI, \%), leaf bend degree $\left(\mathrm{LBD},{ }^{\circ}\right)$ were calculated based on Xiang et al. (2012):

$$
\begin{aligned}
& \mathrm{LRI}=(\mathrm{Lw}-\mathrm{Ln}) / \mathrm{Lw} \times 100 \\
& \mathrm{LEI}=\mathrm{Lnl} / \mathrm{Lsl} \times 100 \\
& \mathrm{LBD}=\text { Drooping angle }- \text { Basic angle. }
\end{aligned}
$$

The plant biomass and grain yield At the end of grain-filling, the tagged plants for measurements of these traits were retrieved, dried at $80^{\circ} \mathrm{C}$ to constant weight in a drying oven, and weighed to obtain the plant root, stem, leaf, and grain biomass.

\subsection{Data statistics}

The statistical analysis was used with SPSS 20.0 software (SPSS Inc., Chicago, IL). One-way ANOVA with Duncan's multiple comparison was used to test the differences in the plant and leaf functional traits and morphological indicators between watering 
treatments at a 0.05 significance level. The differences of functional parameters among watering treatments, leaf positions and measurement dates were tested by the three-way ANOVA at the 0.05 significance level. The correlations between leaf functional and morphological traits were analyzed with Pearson method. The comprehensive patterns of the responses of leaf functional and morphological traits to episodic drought and rewatering were further analyzed with principal component analysis (PCA, Jolliffe 2002).

\section{Results}

\section{1. Photosynthetically physiological responses to drought episode and} rewatering

\subsubsection{Responses in upper leaves}

Photosynthetic physiological parameters were measured during the entire growing season: on 1, July (V13, jointing); 14, July (V21); 25, July (VT, tasselling); 31, July (R1, Silking); 7, August (R2, blistering); 14, August (R3, milking); 29, August (R4, dough), respectively (Table 1). As shown in Figure 1, the upper leaf net light-saturated photosynthetic rate $\left(A_{\text {sat }}\right)$ of control treatment $\left(\mathrm{T}_{1}\right)$ increased with earlier plant development, reaching the maximum of $45.4 \mu \mathrm{mol} \mathrm{m}^{-2} \mathrm{~s}^{-1}$ on 31 July (R1 stage), thereafter sharply decreasing until to a lowest point of $14.1 \mu \mathrm{mol} \mathrm{m} \mathrm{m}^{-2}$ by $68.5 \%$ at later grain-filling stage.

For the $\mathrm{T}_{2}$ treatment (withholding water during jointing - tasseling, 27 days), the episodic drought led to a significant decline of $A_{\text {sat }}$ with a low level of $21.7 \mu \mathrm{mol}$ $\mathrm{m}^{-2} \mathrm{~s}^{-1}$ on 14, July (V21 stage), a $40.3 \%$ drop; and further down to a lower level of $15.6 \mu \mathrm{mol} \mathrm{m} \mathrm{m}^{-2}$ on 25 , July (VT stage), a $65.6 \%$ drop. Upon re-irrigating, it rose up to $24.4 \mu \mathrm{mol} \mathrm{m} \mathrm{m}^{-2}$ by $56.4 \%$ relative to the previous value , but not to reach the level of control treatment at the same stage-a maximum of $45.4 \mu \mathrm{mol} \mathrm{m} \mathrm{s}^{-1}$ for the control plant. It indicated that a 27-day episodic drought from jointing to tasseling significantly inhibited photosynthetic capacity, just a part of recovery when following rewatering occurred, resulting in limitation to plant growth and development, and 
final grain yield loss.

Leaf $A_{\text {sat }}$ of the $\mathrm{T}_{3}$ treatment (withholding water during jointing -anthesis, 41 days) always markedly decreased, even it remained a low and stable level as rewatering and during anthesis, thereafter declined rapidly after milking until to a low level of 6.6 $\mu \mathrm{mol} \mathrm{m} \mathrm{m}^{-2}$ at later grain-filling. The rewatering had a relatively-higher stimulation relative to the control only at milking, indicating the mild stimulation appeared (17.0 vs: $15.4 \mu \mathrm{mol} \mathrm{m} \mathrm{s}^{-1}$, Figure 1a).

While leaf $A_{\text {sat }}$ of the $\mathrm{T}_{4}$ treatment (withholding water during tasseling-milking, 41 days) had an increase at earlier withholding water (silking stage), then sharply declined to a low level of $12.0 \mu \mathrm{mol} \mathrm{m}^{-2} \mathrm{~s}^{-1}$ at blistering, thereafter remaining a lower and stable level until the end of the grain-filling, although this time it seemed to lightly rise relative to $\mathrm{T}_{3}$ treatment, indicating that a stimulation occurred by the just nearly rewatering. Leaf $A_{\text {sat }}$ of the $\mathrm{T}_{5}$ treatment (withholding water during silking-milking, 34 days), similar to $\mathrm{T}_{4}$ but less 7-day drought duration, declined even more sharply. It may indicate that later drought at tasseling may result in more sensitive effect on the gas exchange processes.

Other photosynthetically physiological parameters in the upper leaves showed similar change patterns (Figure $1 \mathrm{~b}-\mathrm{f}$ ): For $\mathrm{T}_{2}$ and $\mathrm{T}_{3}$ plants, $\mathrm{SPAD}, g_{\mathrm{s}}$, and $E$ markedly deceased 4 weeks after withholding water. However, $\Phi_{\mathrm{PSII}}$ and $F_{\mathrm{v}}{ }^{\prime} / F_{\mathrm{m}}{ }^{\prime}$ remained stable. Rewatering for $\mathrm{T}_{2}$ on 27, July, and for $\mathrm{T}_{3}$ on 10 , August, resulted in stimulations in SPAD, $g_{\mathrm{s}}, E, \Phi_{\mathrm{PSII}}$, and $F_{\mathrm{v}}{ }^{\prime} / F_{\mathrm{m}}{ }^{\prime}$; However, they still could not fully recover to the normal level. The drought stresses of $\mathrm{T}_{4}$ and $\mathrm{T}_{5}$ treatments also led to declines in the gas exchange rates, while the chlorophyll fluorescence parameters remained relatively stable except $\mathrm{T}_{4}$ treatment decrease during drought episode and thereafter rewatering.

\subsubsection{Responses in middle leaves}

The changes in photosynthetic capacity of leaves at the plant middle position exhibited a similar change pattern in the upper leaves (Figure 2): As compared to the upper leaves, however, there were lower levels of $A_{\text {sat }}$, SPAD, $g_{\mathrm{s}}$, and $E$ during drought episodes, while rewatering following the pre-drying also did not lead to a complete restoration in the gas exchange parameters and SPAD values at later 
grain-filling stage. The chlorophyll fluorescence parameters still maintained a high level, implying that relatively mature middle leaves may have a drought-resistance in terms of PSII photochemical activities as compared with the younger upper leaves.

\subsubsection{Responses in bottom leaves}

As measured in bottom leaves, there were greater levels in $A_{\text {sat }}$ and SPAD under various water treatments at jointing stage (1, July), declining with plant developing (Figure 3). Plants at normal irrigation (control treatment) showed higher levels in the gas exchange parameters $\left(A_{\mathrm{sat}}, g_{\mathrm{s}}\right.$, and $\left.E\right)$ and SPAD values, while lower levels were found during drought episodes, i.e., under $T_{3}, T_{4}$, and $T_{5}$ treatments. Only part recovery was obtained upon rewatering at end of grain-filling stage in the plants experienced pre-drying history ( $\mathrm{T}_{4}$ and $\mathrm{T}_{5}$ treatments). The chlorophyll fluorescence parameters such as $\Phi_{\mathrm{PSI}}$ and $F_{\mathrm{v}}{ }^{\prime} / F_{\mathrm{m}}{ }^{\prime}$ were maintained at a higher level as the plants were subjected to withholding water treatments, particularly under $T_{3}$ treatment (41-day withholding water during Jointing - anthesis). This again implicates an adaptive response to drought episode in terms of chlorophyll PSII photochemical activities.

The three-way ANOVA showed that watering treatment, leaf position, and measured date produced significant effects on SPAD, $A_{\text {sat }}, E$ and WUE, individually $(P<0.001$; Table 2). Only date alone and the interaction between leaf position and date had significant effects on $g_{\mathrm{s}}(P<0.05)$. The interactions between watering and date, and between leaf position and date significantly affected SPAD, $A_{\text {sat }}$, and $E(P<$ 0.001). Effect of leaf position and date alone, and their interaction on $\Phi_{\mathrm{PSII}}$ were significant; while the significant effect on $F_{\mathrm{v}}{ }^{\prime} / F_{\mathrm{m}}{ }^{\prime}$ from date as single factor, and its interaction with leaf position appeared. The interaction of the three factors was not observed $(P>0.05)$.

The 2015-year experiment obtained the similar results on the responses of the relative chlorophyll content (SPAD values) and photosynthetic potentials mainly indicated by fluorescence parameters to the drought episode and the following rewatering regimes at the same experimental site (see Figures S1-S3). 


\subsection{Photosynthetically physiological responses in the leaves tagged at different developments.}

We measured the same leaves tagged to examine the photosynthetically physiological processes at different plant developments/leaf ages and the responses to episodic drought and rewatering - just staring from emerging of the leaves to becoming fully senesced. As showed in Figure 4, the leaf $A_{\text {sat }}$ increased from the initial stage on first July, reaching a maximum on 25 July; thereafter, linearly declining with plant developing or leaf aging (Figure 4a). A gradual increase in SPAD values was observed initially with a maximum occurrence on 31 July, and a marked decline at end of grain-filling, i.e., 29 August (Figure 4b). Acute declines in $E$ and $g_{\text {s }}$ were obtained after 31 July (Figure 4c,d); whereas the two chlorophyll fluorescence parameters $\left(\Phi_{\mathrm{PSII}}\right.$ and $\left.F_{\mathrm{v}}^{\prime} / F_{\mathrm{m}}{ }^{\prime}\right)$ did not fluctuate greatly (Figure $\left.4 \mathrm{e}, \mathrm{f}\right)$.

As compared to the normal water supply, drought episodes of $\mathrm{T}_{3}, \mathrm{~T}_{4}$, and $\mathrm{T}_{5}$ treatments resulted in the declines in the tagged leaves' gas exchange parameters- $A_{\text {sat, }}, g_{\mathrm{s}}$, and $E$, particularly with a longer drought persistence; while parts of stimulations by rewatering occurred after an episodic drought (Figure 4a,c,d). Decreases in SPAD values were often found as the drying episode occurred, particularly at the end of grain-filling (Figure 4b). We found that the two chlorophyll fluorescence parameters $\left(\Phi_{\mathrm{PSII}}\right.$ and $\left.F_{\mathrm{v}}^{\prime} / F_{\mathrm{m}}\right)$ had a slight response to either drought episodes or following rewatering, even with relative high levels upon the following rewatering (Figure 4e,f). This indicated that, in terms of chlorophyll fluorescence parameters, drought-tolerance may be enhanced with the leaf developing or its aging, this issue may need to be investigated further for different crops and their cultivars.

\subsection{Responses of leaf morphological traits to drought and its relieving.}

Changes in maize plant canopy features (plant height, leaf area), leaf morphologic traits (leaf size, leaf rolling index (LRI), leaf erection index (LEI), leaf bend degree (LBD)) in responses to drought episodes and rewatering were shown in Table 3. The results at first measurement (1 July 2016) showed that no significant changes in plant height, plant individual leaf area, LRI, LEI, and LBD when the plants subjected to the 
normally watering treatments. LRIs of $\mathrm{T}_{2}$ and $\mathrm{T}_{3}$ on 14 July increased significantly due to their undergoing a 15-day drought episode duration. Plants of $T_{2}$ and $T_{3}$ reduced plant height and total leaf area, but increased LRI significantly on 25 July, indicating that the two drought treatments significantly affected plant and leaf growth, and morphological traits and canopy structure. LRI of $\mathrm{T}_{3}$ was greatest under drought on $31 \mathrm{July}$; and that of $\mathrm{T}_{2}$ just following rewatering rapidly decreased relative to the previous measurement; and the treatments of $\mathrm{T}_{2}$ and $\mathrm{T}_{3}$ had higher LBD. On 7 August, LRIs under drought conditions, i.e., $\mathrm{T}_{3}, \mathrm{~T}_{4}$ and $\mathrm{T}_{5}$ treatments, were greater than that of the control, while LEI and LBD were not affected significantly. At milking stage (R3, On 14 August), LRI under $\mathrm{T}_{4}$ treatment was greater significantly, and that of $\mathrm{T}_{2}$ became lower close to control level due to rewatering. At the end of grain-filling stage (measured on 29 August), $T_{2}$ plant leaf area was reduced significantly, whereas LRIs were not significant between the watering treatments. LEIs of $T_{4}$ and $T_{5}$ treatments were lower, indicating nearly rewatering did not trigger plant leaf erections with leaf aging.

\subsection{Relationships between leaf morphological and functional traits in responses} to drought and rewatering.

Relationships between the morphological and functional traits of upper leaves were given in Table 4 . The relationships among SPAD, $A_{\text {sat }}, E, g_{\mathrm{s}}$, and WUE were significant $(P<0.05)$ except the correlations of WUE with $E$ and $g_{\mathrm{s}}$. There were significant relationships between the two chlorophyll fluorescence parameters- $\Phi_{\mathrm{PSII}}$ and $F_{\mathrm{v}}{ }^{\prime} / F_{\mathrm{m}}{ }^{\prime}$ themselves; however, they did not correlate with SPAS values, and with gas exchange parameters $(P>0.05)$. Among plant morphological traits, there were significant and positive associations of plant height with total individual plant leaf area, LBD; but negative with LEI. LEI was significantly and negatively correlated with LBD. Between plant morphological and functional traits, there were significant and negative correlations of plant height with $A_{\mathrm{sat}}, g_{\mathrm{s}}$, WUE, and also those of LRI with SPAD, $A_{\text {sat }}, E, g_{\mathrm{s}}$ and WUE. Significant positive correlations of LEI with $A_{\text {sat }}$ and $g_{\mathrm{s}}$ were found, whereas significant negative correlations of LBD with SPAD, $A_{\text {sat, }}, g_{\mathrm{s}}$ 
and WUE appeared, implicating the two leaf morphological indicators (i.e., LEI and LBD) may play an antagonistic role in the responses to drought episode and rewatering.

To elucidate the critical linkage of the important functional traits such as relationship between the chlorophyll content and photosynthetic capacity in responses to watering treatment regimens at different growth stages, the correlations between SPAD and $A_{\text {sat }}$ were analysed. The results showed that no significant relationship was observed from jointing to tasseling stages (Figure 5a), whereas significant-positive relationships appeared from silking to blistering $\left(\mathrm{R}^{2}=0.12, P<0.001\right)$, and from milking to denting $\left(\mathrm{R}^{2}=0.41, P<0.001\right.$; Figure $\left.5 \mathrm{~b}, \mathrm{c}\right)$, indicating that their correlation becomes stronger with plant developmental process, particularly at later grain-filling. In addition, no significant relationship was found under normal irrigation condition (Figure 5d), meanwhile the significant relationship appeared under drought episode or rewatering treatments (Figure 5e,f), implying that their correlation can be enhanced due to the watering treatments.

Based on the principal component analysis (PCA) on leaf functional and morphological traits at silking stage, the first two principal components (PCs) accounted for $60 \%$ of the total variations of the maize traits (Figure 6). Gas exchange parameters closely positively correlated with principle component one (PC1), while the chlorophyll fluorescence parameters closely positively correlated with principle component two (PC2). There were negative correlations of PC2 with SPAD, plant height, and leaf area. The loadings were well typically distributed: the gas exchange parameters were located on the right side, the two chlorophyll fluorescence parameters upper part. SPAD was put alone on in quadrant III, while LRI was separated separately in quadrant II. Finally, the two plant growth traits ware located on quadrant IV, contrasting to LRI. Plots of the two factor scores demonstrated that the drought episode treatments $\left(\mathrm{T}_{4}\right.$ and $\left.\mathrm{T}_{5}\right)$ were located on right-bottom parts, which is far from the loadings of gas exchange, chlorophyll fluorescence quantum yields. It implicates that the drought episode gave a severe impact on the photosynthetic capacity, and PCA may well represent the change patterns in plant and leaf growth, 
414 morphological and functional responses to the drought episode and rewatering

415 regimes.

\section{Discussion}

418 Maize, as one of most important staple crops, playing critical role in food security and 419 husbandry industry development (Campos et al. 2004; FAO 2017), is being hampered 420 severely by adverse climate change, such as abnormal precipitation alterations and heat wave events. Drought that is been intensifying by global warming is one of major limitations to maize growth and final grain yield (Boyer 1982; Sharp et al. 2004; Lobell et al. 2014; Jiao et al. 2014; Avramova et al. 2015; Myers et al. 2017). Although the effect on crop from drought as a single stress factor is studied extensively, understanding the crop functional processes in responses to drought episode and rewatering is still relatively scant, particularly across an entire plant development. The present results indicated that drought during jointing period produced severe effects on vegetative growth and photosynthetic capacity, while continuous drought during tasseling greatly-negatively impacted the reproductive growth and leaf photosynthetic capacity. Rewatering could alleviate adverse effects of pre-drought, but not stimulate both vegetative and reproductive growth and photosynthetic activities to recover fully to the levels of the control. Meanwhile, the leaf chlorophyll fluorescence parameters showed a relatively-stable and adaptive changes in response to episodic drying regimes. Moreover, the leaf functional traits mostly significantly negatively correlated with morphological indicators, and leaf rolling index (LRI) could be a sensitive indicator to assess the response of plants to drought and rewatering. Moreover, the association of light-saturated net photosynthetic rate $\left(A_{\text {sat }}\right)$ with chlorophyll content (SPAD value) can be as an effective proxy of leaf aging and the drought episodic durations. The present results may provide a newly profound insight into understanding the crops' adaptive mechanism to drought cycle and rewatering regimes, and might be useful for the drought-resistant breeding practices and water-saving irrigation managements.

443 Nevertheless, the future models have well predicted that more extreme climate 444 events will happen by the end of this century, making drought severer and heat waves more frequently (Luterbacher et al. 2004; Schär et al. 2004; IPCC 2014). The

446 consequences of water availability loss have a marked influence on crop growth and 
447 productivity (Stuhlfauth et al.1990; Ciais et al. 2005; Chaves et al. 2009), finally

448 reducing the quantity and quality of grain yield (Marco \& Tricoli.1993; Serraj \&

449 Sinclair. 2002; Barnabás et al. 2008; Lobell et al. 2014), and threatening food security regionally even globally (Ghannoum 2009; Myers et al. 2017). Among them, photosynthesis - the fundamental process for determination of crop growth and its development, even the final grain yield, is primarily affected by crucial climatic change factors such as drought (e.g., Boyer 1982; Chaves et al. 1991; Jefferies et al. 1994; Angelopoulos et al.1996; Farooq et al. 2009; Shen et al. 2015). The current results indicated that changes in the photosynthetically physiological parameters of the upper leaves are most significantly different between the different irrigation treatments $(P<0.05)$. Compared with control, under drought episode, the net light-saturated photosynthetic rate $\left(A_{\text {sat }}\right)$, chlorophyll content (SPAD value), stomatal conductance $\left(g_{\mathrm{s}}\right)$, and transpiration rate $(E)$, significantly decreased, while the actual quantum efficiency of PSII ( $\left.\Phi_{\text {PSII }}\right)$, the effective quantum yield of PSII photochemistry $\left(F_{\mathrm{v}}^{\prime} / F_{\mathrm{m}}{ }^{\prime}\right)$ were no significantly declined. The previous experiments showed that the net photosynthesis rate decreases with $g_{\text {s }}$ dropping (Tenhunen 1987; Jarvis \& Davies 1998; Miyashita et al. 2005). A decrease in $g_{\mathrm{s}}$ will reduce water loss under drought stress, which also generates a drop in $\mathrm{CO}_{2}$ uptake (Frederick et al. 1989; Miyashita et al. 2005). When the plants of $\mathrm{T}_{2}$ treatment (pre-anthesis drought episode) was re-watered on 27 July, the photosynthetic parameters of leaves such as $A_{\text {sat, }}$ SPAD, $g_{\mathrm{s}}, \mathrm{E}, \Phi_{\mathrm{PSII}}$ and $F_{\mathrm{v}}{ }^{\prime} / F_{\mathrm{m}}{ }^{\prime}$ mostly harmonically increased by the rewatering following the pre-drought episode; the similar responses to rewatering also occurred under $T_{3}, T_{4}$ and $\mathrm{T}_{5}$ treatments (Figures 1-3). As reported, precipitation events could generate a rapid response of the plant biological processes, which can trigger plants growth and development (e.g., Acevedo et al. 1971; Reynolds et al. 2004), but the values of 472 photosynthetic parameters generally were lower than control level (Xu et al. 2009; Xu et a1. 2010; Suralta et al. 2017). The results illustrated the continuous drought 474 constrained photosynthetic capacity of the upper leaves, and the following rewatering is unable to totally recover to normal level (Figures 1 \& 4). As reported previously, 
477 of pre-drought (Xu \& Zhou 2007; Chen et al. 2009; Xu et al. 2009, 2010; Abid et al. 478 2016).

479 The change patterns of middle leaves' photosynthetic parameters were similar to those of the upper leaves (Figures 1-3): Under the normal treatment, SPAD, $A_{\text {sat }}, g_{\mathrm{s}}, \mathrm{E}$, remained at a higher level compared with drought episodes $\left(\mathrm{T}_{3}, \mathrm{~T}_{4}\right.$, and $\mathrm{T}_{5}$ treatments). Rewatering did not promote the photosynthetic capacities of $\mathrm{T}_{4}, \mathrm{~T}_{5}$ at the grain-filling. In relation to the chlorophyll fluorescence parameters, which has been ones of the most practical and extensively used indicators to analysis plant eco-physiological processes (e.g., Maxwell \& Johnson. 2000). Of them, $F_{\mathrm{v}} / F_{\mathrm{m}}$ ', as most useful one, often ranges between 0.80 and 0.83 without photoinhibition (Björkman \& Demmig 1987). After suffering from severe water deficit stress, however, $F_{\mathrm{v}}{ }^{\prime} / F_{\mathrm{m}}{ }^{\prime}$ would decrease (Epron et al. 1992; Souza et al. 2004). However, our results showed both $F_{\mathrm{v}}{ }^{\prime} / F_{\mathrm{m}}{ }^{\prime}$ and $\Phi_{\mathrm{PSII}}$ can maintain a high level even under severe drought. The results may explain that the middle leaves' period of growth and development is longer, compared with the upper leaves. It may demonstrate a higher drought adaptability in the photochemical process and play a critical role in plant biomass accumulation and final grain yield (also see Allison \& Watson 1966; Xu et al. 2008, 2011; Chen et al. 2016). For the bottom layer leaves, SPAD and $A_{\text {sat }}$ were highest at the jointing stage (first measured on 1 July). Since then, they decreased with plant growing. The influence of drought on the bottom leaves was also consistent with the upper ones. SPAD and gas exchange parameters were also reduced markedly by the drought episode. At the end of grain-filling stage (24 August), the stimulating effect of rewatering was also lost partly. The two chlorophyll fluorescence parameters, however, remained higher under and after drought, especially at the end of grain-filling stage (e.g., withholding water from jointing to anthesis stages, total 41-day drought episode). It may again reflect the 502 adaptive ability of maize elder leaves' photochemical activity in responses to drought episodes and thereafter rewetting.

504 The results of the tagged leaves showed that along with the growth of the same leaf, 505 the changing trends of the photosynthetic physiological parameters under each treatment were various (Figure 4): under control treatment, $A_{\text {sat }}$ remained at a low 
507 level measured on 1 July, reaching a maximum on 25 July, thereafter linearly 508 declining. SPAD reached a maximum on 31 July, thereafter significantly decreasing 509 until grain-filling stage (29 August). Stomatal conductance and $E$ decreased sharply 510 after 31 July, whereas the changes in chlorophyll fluorescence parameters $\left(\Phi_{\text {PSII }}\right.$, $\left.511 \quad F_{\mathrm{v}}^{\prime} / F_{\mathrm{m}}{ }^{\prime}\right)$ remained stable. The relative chlorophyll content and leaf gas exchange 512 parameters of leaves in normally irrigated plants were at a high level, while those of 513 the plants drought-stricken treatments $\left(T_{3}, T_{4}\right.$ and $T_{5}$ treatments $)$ were at a low level, 514 especially at the later grain-filling stage. It may highlight the leaf senescence process 515 and its enhancement by drought stress (also see Xu et al. 2008; 2010). Rewatering can 516 trigger gas exchange process; the chlorophyll fluorescence parameters $\left(\Phi_{\mathrm{PSII}}, F_{\mathrm{v}}{ }^{\prime} / F_{\mathrm{m}}{ }^{\prime}\right)$, 517 however, were less affected by drought stress and rehydration (Lu \& Zhang 1999; but 518 Ghannoum et al. 2003; Gallé et al. 2007). Above all, the results again indicated that 519 the drought-tolerance of the chlorophyll fluorescence parameters may increase with 520 the plant/leaf growth and development when as measured in the same leaves (e.g., the tagged leaves). This issue remains debated, and needs the further research.

522 With the progresses of the maize plant and leaf growth, the photosynthetic performances of the upper, middle and lower leaves and the marked leaves of the maize may gradually decrease under moderate and severe drought stresses, and then recover partly after rewatering, which was consistent with previous research results (e.g., Flexas et al. 2009; Vaz et al. 2010; Xu et al. 2011). The current results also found that the photosynthetic performance of the middle leaves was higher than those of the both upper and lower leaves. The reasons may be due to the middle leaves being longer and greater than the upper one, and continuous drought may exacerbate further premature senescence of the bottom leaves (Iacono \& Sommer 2000; Lu et al. 2001; He et al. 2002; Xu et al. 2011). Thus, the middle leave has stronger

532 photosynthetic performances than both the upper and the lower ones, and it may contribute to most of carbon accumulation as plants exposed to drought episode and 534 the following rewetting.

535 The sensitivity of crop yield to water deficits often markedly differs at different 
$537 \&$ Soriano 2007)—Generally, staple crops including maize are more sensitive to water

538 deficit during seedling emergence, flowering, and early grain-filling than those during

539 early plant growth and late grain-filling periods (e.g., Doorenbos \& Kassam 1979).

540 Under non-lethal water deficit during early vegetative growth, marked reductions in

541 maize plant height and biomass were often found, and its crop phenology could delay,

542 but this may not closely link to a lower yield potential (Damptey \& Aspinall 1976;

543 Abrecht \& Carberry 1993). However, maize plant at jointing stage has exuberantly

544 metabolic activities; under drought condition, the inhibition of plant height from

545 jointing stage to tasseling stage was significantly greater than those at other stages

546 (NeSmith \& Ritchie 1992; Earl \& Davis 2003). Therefore, the treatment with

547 withholding water during the jointing period would mainly affect plant vegetative

548 growth, leading to vegetative growth inhibition with short plant size, small leaves and

549 internodes, and delays of tassel emergence, silk emergence, and onset of grain filling,

550 finally a grain yield loss by 15-25\% (Damptey \& Aspinall 1976; NeSmith \& Ritchie

551 1992). The current results indicated that the pre-anthesis drought significantly affected

552 plant height and leaf size, even the canopy structure (and also see Earl \& Davis 2003;

553 Ne Smith \& Ritchie 1992). Cakir (2004) found that the water content in the early

554 growth stage of maize has great influence on plant height, consequently resulting in

555 decline in canopy absorption of photosynthetically active radiation (PAR, Earl \&

556 Davis 2003). Thus, an early pre-anthesis water deficit might also not be neglected to

557 obtain high yield even high in maize field, particularly with the severe and

558 consecutive drought events (also see Ne Smith \& Ritchie 1992). Our results

559 manifested that the pre-anthesis drought markedly limited vegetative growth, lead to

560 the declines in plant height and leaf area; and although the rehydration could alleviate

561 the adverse effects from drought, it could not return fully to normal level at either

562 early or later plant development stages. It highlights the drought constraints to maize

563 plant growth during not only drought-persisting but drought-relieving periods.

564 Additionally, leaf rolling index (LRI, Xiang et al. 2012), as a key parameter of plant

565 morphological characteristics, obviously increased during drought episodes, but

566 immediately decreased by rewatering. Therefore, it is suggested that the easy changes 
567 in LRI can be as a sensitive indicator for sensing drought and rewatering during

568 almost entire plant growing season.

569 As stated above, drought stress seriously affected the photosynthesis of maize,

570 inhibited the growth and development, and eventually leading to drops in plant

571 biomass and yield (Irigoyen et al.1996; Bruce et al. 2002; Zhang et al. 2012). Maize

572 grain yield is highly sensitive to drought during tasseling-silking period, mainly due

573 to the marked decline in grain number (Otegui et al. 1995; Bolanos \& Edmeades 1996;

574 Barnabás et al. 2008). Our results also found that although the plants of $T_{4}$ and $T_{5}$

575 treatments were normally irrigated at jointing stage, the episodic drought at later

576 tasseling stage, the ear growth was still significantly constrained relative to the control

577 group. The current results of $\mathrm{T}_{4}$ and $\mathrm{T}_{5}$ treatments (pro-anthesis drought) showed no

578 significant effect of drought at tasseling stage on the earlier plant growth. It again

579 highlights that the later drought may exert a greatly adversely influence on the

580 reproductive growth of maize plants.

581 The analysis on the correlation and principal component analysis reveal that there

582 were positive correlations between the functional traits, except those with $\Phi_{\text {PSII }}$ and

$583 \quad F_{\mathrm{v}}{ }^{\prime} / F_{\mathrm{m}}{ }^{\prime}$; although a positive correlation themselves between $\Phi_{\mathrm{PSII}}$ and $F_{\mathrm{v}}{ }^{\prime} / F_{\mathrm{m}}{ }^{\prime}$ was

584 found. A significant-positive correlation between plant height and total leaf area, and a

585 negative correlation between functional traits and morphological parameters occurred.

586 SPAD is recognized an ideal non-destructive method for testing chlorophyll status in

587 plant leaves, it has been widely used to investigate the environmental adaptability of

588 crops (Manetas et al. 1998; Uddling et al. 2007; Steele et al. 2008; Ciganda et al.

589 2009; Pour-Aboughadareh et al. 2017). Interestingly, with the development of maize

590 growth, the correlation of $A_{\text {sat }}$ and SPAD was more positive and stronger, particularly

591 under drought and rehydration conditions (Figure 5). Some results showed that the

592 values of SPAD had a higher correlation with actual chlorophyll content under the

593 conditions of lower actual chlorophyll content levels (Steele et al. 2008; Ciganda et al.

594 2009), depending on species and the chlorophyll distribution on leaf (Uddling et al.

595 2007). Therefore, probably maize plants grew at later growth stage and moisture

596 condition became stressful, it may lead to reductions in both actual chlorophyll 
597 content and photosynthetic performance. Thus, the relationship between $A_{\text {sat }}$ and 598 SPAD might become more positive and closer (Figure 5). It is indicated that the 599 relationships among the functional traits of leaves would alter with plant development 600 and environmental changes, which may become closer and stronger with senescing at 601 the later growth stage and especially under adverse environmental conditions.

602 In conclusion, from the current field experiment, episodic drought may exert 603 markedly negative effects on photosynthetic potentials at either pre-anthesis or 604 post-anthesis stages, particularly during early grain-filling; and the rapid recovery of 605 leaf photosynthetic activities following re-irrigating occurred, but the recovery 606 magnitude and rate might depend on the severity and persistence of the previous 607 drought, and the leaf age and plant development. Generally, the leaf gas exchange, 608 and leaf rolling index may demonstrate higher sensitivity to drought episode and thereafter rewatering than these chlorophyll content and its fluorescence parameters. The results would provide a profound insight into how to understand the crop functional traits' responses to various drought stresses and precipitation or irrigation

612 regimes. Finding the appropriate indicators for delayed leaf senescence while increased/stabilized photosynthetic potentials under changing water status may assist us in well dealing with climatic change to ensure crop production stability (Xu et al. 2010; Chen et al. 2013; Ben-Ari et al. 2016). Nevertheless, unambiguous understanding the underlying mechanisms of molecular and eco-physiological responses to various drought events, and helping the staple crops to cope with future climatic change to guarantee food security regionally and globally still remain a huge challenge, and that needs to be investigated further (Lobell et al. 2014; Gray et al. 2016; Myers et al. 2017).

\section{Acknowledgements}

The study was funded by the National Natural Science Foundation of China 624 (41330531), and China Special Fund for Meteorological Research in the Public Interest (GYHY201506019). The authors are grateful to Na Mi, Fu Cai, Kunqiao Shi,

626 Yang Yang, Quanhui Ma for their work during the experiment. 


\section{Availability of data and materials}

629 The data sets supporting the results of this article are included within the article and 630 its supporting information file.

\section{Authors' contributions}

633 ZX and GZ conceived and designed the study; HS, YL, LZ, ZX conducted the authors approved the final manuscript.

\section{Competing interests}

The authors declare that they have no competing interests.

\section{References}

641 Abendroth L, Elmore R, Hartzler RG, McGrath C, Mueller DS, Munkvold GP, Pope R, Rice ME,

642 Robertson AE, Sawyer JE, Schaefer KJP, Tollefson JJ, Tylka GL. (2009) Corn Field Guide.

643 Extension and Outreach Publications. Book 26. http://lib.dr.iastate.edu/extension_pubs/26.

\section{$644 \quad$ Verified 21 July 2017.}

Abid M, Tian Z, Ata-Ul-Karim ST, Wang F, Liu Y, Zahoor R, et al. (2016). Adaptation to and recovery from drought stress at vegetative stages in wheat (Triticum aestivum) cultivars. Funct. Plant Biol. 43, 1159-1169. growth, development and yield. Field Crops Res. 31, 55-69.

Acevedo E, Hsiao TC, Henderson DW. (1971). Immediate and subsequent growth responses of maize leaves to changes in water statues. Plant Physiol. 48, 631-636.

Alley RB, Marotzke J, Nordhaus WD, Overpeck JT, Peteet DM, Pielke RA, et al. (2003). Abrupt climate change. Science, 299, 2005-2010.

Allison JCS, Watson DJ. (1966). The production and distribution of dry matter in maize after flowering. Ann. Bot. 30, 365-381. europaea L.) during water stress and rewatering. J. Exp. Bot. 47, 1093-1100. 
662

663

664

665

666

667

668

669

670

671

672

673

674

675

676

677

678

679

680

681

682

683

684

685

686

687

688

689

690

691

692

693

694

695

696

697

698

699

700

Barnabás B, Jäger K, Fehér A. (2008). The effect of drought and heat stress on reproductive processes in cereals. Plant Cell Environ. 31, 11-38.

Barnabás B, Jäger K, Fehér A. (2008). The effect of drought and heat stress on reproductive processes in cereals. Plant Cell Environ. 31, 11-38.

Battisti David S, Naylor Rosamond L. (2009). Seeds of doubt response. Science 324, 179-179.

Ben-Ari T, Adrian J, Klein T, Calanca P, Van der Velde M, Makowski D. (2016). Identifying indicators for extreme wheat and maize yield losses. Agr. Forest Meteorol. 220, 130-140.

Björkman O, Demmig B. (1987). Photon yield of $\mathrm{O}_{2}$ evolution and chlorophyll fluorescence characteristics at $77 \mathrm{~K}$ among vascular plants of diverse origins. Planta 170, 489-504.

Bolanos J, Edmeades GO. 1996. The importance of the anthesis-silking interval in breeding for drought tolerance in tropical maize. Field Crops Res. 48:65-80.

Boyer JS (1982) Plant productivity and environment. Science 218, 443-448.

Bruce WB, Edmeades GO, Barker TC. (2002). Molecular and physiological approaches to maize improvement for drought tolerance. J. Exp. Bot. 53, 13-25.

Çakir R. (2004). Effect of water stress at different development stages on vegetative and reproductive growth of corn. Field Crops Res. 89, 1-16.

Campos H, Cooper A, Habben JE, Edmeades GO, Schussler JR (2004) Improving drought tolerance in maize: a view from industry. Field Crop. Res. 90, 19-34.

Chaves MM, Flexas J, Pinheiro C. (2009). Photosynthesis under drought and salt stress: regulation mechanisms from whole plant to cell. Ann. Bot. 103, 551-560.

Chaves MM, Pereira JS, Maroco J, Rodrigues ML, Ricardo CPP, Osório ML, Pinheiro C. (2002). How plants cope with water stress in the field. Photosynthesis and growth. Ann Bot. 89, 907-916.

Chaves MM. (1991). Effects of water deficits on carbon assimilation. J. Exp. Bot. 42, 1-16.

Chen S, Lin G, Huang J, Jenerette GD. (2009). Dependence of carbon sequestration on the differential responses of ecosystem photosynthesis and respiration to rain pulses in a semiarid steppe. Glob. Change Biol. 15, 2450-2461.

Chen X, Chen F, Chen Y, Gao Q, Yang X, Yuan L, et al. (2013). Modern maize hybrids in Northeast China exhibit increased yield potential and resource use efficiency despite adverse climate change. Glob. Change Biol. 19, 923-936.

Chen Y, Wu D, Mu X, Xiao C, Chen F, Yuan L, Mi G. (2016). Vertical distribution of photosynthetic nitrogen use efficiency and its response to nitrogen in field-grown maize. Crop Sci. 56, 397-407.

Ciais P, Reichstein M, Viovy N, Granier A, Ogée J, Allard V, et al. (2005). Europe-wide reduction in primary productivity caused by the heat and drought in 2003. Nature 437, 529-533.

Ciganda V, Gitelson A, Schepers J. (2009). Non-destructive determination of maize leaf and canopy chlorophyll content. J. Plant Physiol. 166, 157-167.

Damptey HB, Aspinall D. (1976). Water deficit and inflorescence development in Zea mays L. Ann. Bot. 40, 23-35. 
701

702

703

704

705

706

707

708

709

710

711

712

713

714

715

716

717

718

719

720

721

722

723

724

725

726

727

728

729

730

731

732

733

734

735

736

737

738

739

Doorenbos J, Kassam AH. (1979). Yield response to water. Irrigation and drainage paper 33:257.

Earl HJ, Davis RF. (2003). Effect of drought stress on leaf and whole canopy radiation use efficiency and yield of maize. Agron. J. 95, 688-696.

Epron D, Dreyer E, Breda N. (1992). Photosynthesis of oak trees [Quercus petraea (Matt.) Liebl.] during drought under field conditions: diurnal course of net $\mathrm{CO}_{2}$ assimilation and photochemical efficiency of photosystem II. Plant Cell Environ. 15, 809-820.

FAO. (2107). FAOSTAT. http://www.fao.org/faostat/en/\#data. Verified 21 July 2017.

Farooq M, Wahid A, Kobayashi N, Fujita D, Basra SMA. (2009). Plant drought stress: effects, mechanisms and management. In Sustainable agriculture (pp. 153-188). Springer Netherlands.

FereresE, Soriano MA. (2007). Deficit irrigation for reducing agricultural water use. J. Exp. Bot. $58,147-159$.

Flexas J, Barón M, Bota J, Ducruet JM, Gallé A, Galmés J, et al. (2009). Photosynthesis limitations during water stress acclimation and recovery in the drought-adapted vitis hybrid Richter-110 (V. berlandieri× V. rupestris). J. Exp. Bot. 60, 2361-2377.

Flexas J, Bota J, Loreta F, Cornic G, Sharkey TD. (2004). Diffusive and metabolic limitations to photosynthesis under drought and salinity in $\mathrm{C}_{3}$ plants. Plant Biol. 6, 1-11.

Francis CA, Rutger JN, Palmer AFE. (1969). A Rapid method for plant leaf area estimation in maize (Zea mays L.). Crop Sci. 9, 537-539.

Frederick JR, Alm DM, Hesketh JD. (1989). Leaf photosynthetic rates, stomatal resistances, and internal $\mathrm{CO}_{2}$ concentrations of soybean cultivars under drought stress. Photosynthetica 23, 575-584.

Gallé A, Haldimann P, Feller U. (2007). Photosynthetic performance and water relations in young pubescent oak (Quercus pubescens) trees during drought stress and recovery. New Phytol. 174, 799-810.

Genty B, Briantais J-M, Baker NR. (1989). The relationship between the quantum yield of photosynthetic electron transport and quenching of chlorophyll fluorescence. Biochimica et Biophysica Acta 990, 87-92.

Ghannoum O, Conroy JP, Driscoll SP, Paul MJ, Foyer CH, Lawlor DW. (2003). Nonstomatal limitations are responsible for drought induced photosynthetic inhibition in four $\mathrm{C}_{4}$ grasses. New Phytol. 159, 599-608.

Ghannoum O. (2009). C 4 photosynthesis and water stress. Ann. Bot. 103, 635-644.

Gray SB, Dermody O, Klein SP, Locke AM, McGrath JM, et al. (2016). Intensifying drought eliminates the expected benefits of elevated carbon dioxide for soybean. Nature Plants 2, 16132. doi:10.1038/nplants.2016.132.

Han GX, Zhou GS, Xu ZZ, Yang Y, Liu JL, Shi KQ. (2007). Soil temperature and biotic factors drive the seasonal variation of soil respiration in a maize (Zea mays L.) agricultural ecosystem. Plant Soil 291, 15-26.

Harrison MT, Tardieu F, Dong Z, Messina CD, Hammer GL. (2014). Characterizing drought stress and trait influence on maize yield under current and future conditions. Glob. Change Biol. 20, 
867-878.

He P, Osaki M, Takebe M, Shinano T. (2002). Changes of photosynthetic characteristics in relation to leaf senescence in two maize hybrids with different senescent appearance. Photosynthetica $40,547-552$.

Hsiao TC. (1973). Plant responses to water stress. Annu. Rev. Plant Physiol. 24, 519-570.

Iacono F, Sommer KJ (2000) Response of electron transport rate of water stress-affected grapevines: influence of leaf age. VITIS 39, 137-144.

IPCC. (2014). Climate Change 2014: Impacts, Adaptation, and Vulnerability. Part A: Global and Sectoral Aspects. Contribution of Working Group II to the Fifth Assessment Report of the Intergovernmental Panel on Climate Change, ed. CB Field, VR Barros, DJ Dokken, KJ Mach, MD Mastrandrea, et al. Cambridge University Press, Cambridge, United Kingdom and New York, NY, USA

Irigoyen JJ, Juan JP, Sanchez-Diaz MAN. (1996). Drought enhances chilling tolerance in a chilling-sensitive maize (Zea mays) variety. New Phytol. 134, 53-59.

Iversen C, Norby R. (2014). Terrestrial plant productivity and carbon allocation in a changing climate. In B. Freedman, Global Environmental Change (pp. 297-316). Springer Netherlands.

Jarvis AJ, Davies WJ. (1998). The coupled response of stomatal conductance to photosynthesis and transpiration. J. Exp. Bot., 49, 399-406.

Jefferies RA. (1994). Drought and chlorophyll fluorescence in field-grown potato (Solanum tuberosum). Physiol. Plant. 90, 93-97.

Jolliffe IT (2002) Principal component analysis. Springer, New York.

Jiao HY, Zhou GS, Chen ZL. (2014). Blue paper about agricultural issues on climate change. Assessment Report on Effect of Climate Change on China' Agriculture (No.1). p1-6. Beijing: Social Science Literature Press.

Kramer DM, Johnson G, Kiirats O, Edwards GE. (2004). New fluorescence parameters for the determination of QA redox state and excitation energy fluxes. Photosynth. Res. 79, 209-218.

Lobell DB, Bänziger M, Magorokosho C, Vivek B. (2011). Nonlinear heat effects on African maize as evidenced by historical yield trials. Nat. Clim. Change 1, 42-45.

Lobell DB, Roberts MJ, Schlenker W, Braun N, Little BB, Rejesus RM, Hammer GL. (2014). Greater sensitivity to drought accompanies maize yield increase in the US Midwest. Science 344, 516-519.

Loewenstein NJ, Pallardy SG. (2002). Influence of a drying cycle on post-drought xylem sap abscisic acid and stomatal responses in young temperate deciduous angiosperms. New Phytol. $156,351-361$.

Long SP, Zhu X-G, Naidu SL, Ort DR. (2006). Can improvement in photosynthesis increase crop yields? Plant Cell Environ. 29, 315-330.

Lu C, Lu Q, Zhang J, Kuang T. (2001). Xanthophyll cycle, light energy dissipation and photosystem II down-regulation in senescent leaves of wheat plants grown in the field. Aust $J$. Plant Physiol. 28:1023-1030. 
Lu C, Zhang J. (1999). Effects of water stress on photosystem II photochemistry and its thermostability in wheat plants. J. Exp. Bot. 50, 1199-1206.

Luterbacher J, Dietrich D, Xoplaki E, Grosjean M, Wanner H. (2004). European seasonal and annual temperature variability, trends, and extremes since 1500. Science 303, 1499-1503.

Manetas Y, Grammatikopoulos G, Kyparissis A. (1998). The use of the portable, non-destructive, SPAD-502 (Minolta) chlorophyll meter with leaves of varying trichome density and anthocyanin content. J. Plant Physiol. 153(3-4), 513-516.

Marco GD, Tricoli, D. (1993). Effect of water deficit on photosynthesis and electron transport in wheat grown in a natural environment. J. Plant Physiol. 142, 156-160.

Marron N, Dreyer E, Boudouresque E, Delay D, Petit J-M, Delmotte FM, Brignolas F. (2003). Impact of successive drought and re-watering cycles on growth and specific leaf area of two Populus $\times$ canadensis (Moench)clones, 'Dorskamp' and 'Luisa Avanzo'. Tree Physiol. 23, $1225-1235$.

Ma X, Ma Y. (2017). The spatiotemporal variation analysis of virtual water for agriculture and livestock husbandry: A study for Jilin province in China. Sci. Total Environ. 586, 1150-1161.

Maxwell K, Johnson GN. (2000). Chlorophyll fluorescence-a practical guide. J. Exp. Bot. 51, 659-668.

Meng Q, Hou P, Wu L, Chen X, Cui Z, Zhang F. (2013). Understanding production potentials and yield gaps in intensive maize production in China. Field Crops Res. 143, 91-97.

Meyer E, Aspinwall MJ, Lowry DB, Palacio-Mejía JD, Logan TL, Fay PA, Juenger TE. 2014. Integrating transcriptional metabolomic, and physiological responses to drought stress and recovery in switchgrass (Panicum virgatum L.). BMC Genom. 15, 527-542.

Miyashita K, Tanakamaru S, Maitani T, Kimura K. (2005). Recovery responses of photosynthesis, transpiration, and stomatal conductance in kidney bean following drought stress. Environ. Exp. Bot. 53(2), 205-214.

Myers SS, Smith MR, Guth S, et al. (2017). Climate change and global food systems: potential impacts on food security and undernutrition. Annu. Rev. Public Health doi: 10.1146/annurev-publhealth-031816-044356. In Press.

Ne Smith DS, Ritchie JT. (1992). Short and long term responses of corn to a pre anthesis soil water deficit. Agron. J. 84, 107-113.

Otegui ME, Andrade FH, Suero EE. (1995). Growth, water use, and kernel abortion of maize subjected to drought at silking. Field Crops Res. 40, 87-94.

PINC. (2017). Crops Database. Planting Information Network of China. http://zzys.agri.gov.cn/nongqing.aspx, Verified, 21 July, 2017.

Pinheriro C, Passarinho JA, Ricardo CP. (2004). Effect of drought and rewatering on the metabolism of Lupinus albus organs. J Plant Physiol 161, 1203-1210

Pour-Aboughadareh A, Ahmadi J, Mehrabi AA, Etminan A, Moghaddam M, Siddique KH. (2017). Physiological responses to drought stress in wild relatives of wheat: implications for wheat improvement. Acta Physiol. Plant. 39, 106. doi:10.1007/s11738-017-2403-z. In Press. 
818

819

820

821

822

823

824

825

826

827

828

829

830

831

832

833

834

835

836

837

838

839

840

841

842

843

844

845

846

847

848

849

850

851

852

853

854

855

856

Reynolds JF, Kemp PR, Ogle K, Fernández RJ. (2004). Modifying the 'pulse-reserve' paradigm for deserts of north America: precipitation pulses, soil water, and plant responses. Oecologia 141, 194-210.

Ribaut J-M, Betran J, Monneveux P, Setter T. (2009). Drought tolerance in maize. In: Bennetzen JL \& Hake SC. (eds.), Handbook of Maize: Its Biology. p311-344. Springer Science + Business Media.

Rurinda J, Mapfumo P, van Wijk MT, Mtambanengwe F, Rufino MC, Chikowo R, Giller KE. (2014). Comparative assessment of maize, finger millet and sorghum for household food security in the face of increasing climatic risk. Eur. J. Agron. 55, 29-41.

Saini HS, Westgate ME. (1999). Reproductive development in grain crops during drought. $A d v$. Agron. 68, 59-96.

Schär C, Vidale PL, Lüthi D, Frei C, Häberli C, Liniger MA, et al. (2004). The role of increasing temperature variability in european summer heatwaves. Nature 427(6972), 332-6.

Serraj R, Sinclair TR. (2002). Osmolyte accumulation: can it really help increase crop yield under drought conditions? Plant Cell Environ. 25, 333-341.

Sharp RE, Poroyko V, Hejlek LG, Spollen WG, Springer GK, Bohnert HJ, Nguyen HT (2004) Root growth maintenance during water deficits: physiology to functional genomes. J. Exp. Bot. $55,2343-2351$.

Shen X, Dong Z, Chen Y. (2015). Drought and UV-B radiation effect on photosynthesis and antioxidant parameters in soybean and maize. Acta Physiol. Plant. 37, 1-8.

Souza RP, Machado EC, Silva JAB, Lagôa AMMA, Silveira JAG. (2004). Photosynthetic gas exchange, chlorophyll fluorescence and some associated metabolic changes in cowpea (Vigna unguiculata) during water stress and recovery. Environ. Exp. Bot. 51, 45-56.

Steele MR, Gitelson AA, Rundquist DC. (2008). A comparison of two techniques for nondestructive measurement of chlorophyll content in grapevine leaves. Agron. J. 100, 779-782.

Stuhlfauth T, Scheuermann R, Fock HP. (1990). Light energy dissipation under water stress conditions contribution of reassimilation and evidence for additional processes. Plant Physiol. 92, 1053-61.

Sun C, Gao X, Chen X, Fu J, Zhang Y. (2016). Metabolic and growth responses of maize to successive drought and re-watering cycles. Agr. Water Manag. 172, 62-73.

Suralta RR, Kano-Nakata M, Niones JM, Inukai Y, Kameoka E, Tran TT, et al. (2017). Root plasticity for maintenance of productivity under abiotic stressed soil environments in rice: Progress and prospects. Field Crops Res. doi:10.1016/j.fcr.2016.06.023. In Press.

Taylor HM, Jordan WR, Sinclair TR. (1983). Limitations to efficient water use in production. Madison, WIASA, CSSA, SSSA.

Tenhunen JD, Pearcy RW, Lange and OL. (1987). Diurnal variations in leaf conductance and gas exchange in natural environments. In: Zeiger, Farquhar GD \& Cowan IR (eds), Stomatal Function, p323. Stanford University Press, Stanford, California. 
857

858

859

860

861

862

863

864

865

866

867

868

869

870

871

872

873

874

875

876

877

878

879

880

881

882

883

884

885

886

887

888

889

890

891

892

893

894

895

Trenberth KE, Dai A, Van Der Schrier G, Jones PD, Barichivich J, Briffa KR, Sheffield J. (2014). Global warming and changes in drought. Nat. Clim. Change 4, 17-22.

Uddling J, Gelang-Alfredsson J, Piikki K, Pleijel H. (2007). Evaluating the relationship between leaf chlorophyll concentration and SPAD-502 chlorophyll meter readings. Photosynth. Res. 91, $37-46$.

van Kooten O, Snel JFH. (1990). The use of chlorophyll fluorescence nomenclature in plant stress physiology. Photosynth. Res. 25, 147-150.

Vaz M, Pereira JS, Gazarini LC, David TS, David JS, Rodrigues A, et al. (2010). Drought-induced photosynthetic inhibition and autumn recovery in two Mediterranean oak species (Quercus ilex and Quercus suber). Tree Physiol. 30, 946-956.

Xiang JJ, Zhang GH, Qian Q, Xue HW. (2012). Semi-rolled leaf1 encodes a putative glycosylphosphatidylinositol-anchored protein and modulates rice leaf rolling by regulating the formation of bulliform cells. Plant Physiol. 159, 1488-1500.

Xu ZZ, Zhou GS. (2007). Photosynthetic recovery of a perennial grass Leymus chinensis after different periods of soil drought. Plant Prod. Sci. 10, 277-285.

Xu ZZ, Zhou GS, Han GX, Li YJ. (2011). Photosynthetic potential and its association with lipid peroxidation in response to high temperature at different leaf ages in maize. J. Plant Growth Regul. 30, 41-50.

Xu ZZ, Zhou GS, Shimizu H. (2010). Plant responses to drought and rewatering. Plant Signal. Behav. 5, 649-654.

Xu ZZ, Zhou GS, Shimizu H. (2009). Are plant growth and photosynthesis limited by pre-drought following rewatering in grass? J. Exp. Bot. 60, 3737-3749.

Xu ZZ, Zhou GS, Wang YL, Han GX, Li YJ. (2008). Changes in chlorophyll fluorescence in maize plants with imposed rapid dehydration at different leaf ages. J. Plant Growth Regul. 27, 83-92.

Xu ZZ, Zhou GS. (2007). Photosynthetic recovery of a perennial grass after different periods of soil drought. Plant Production Sci. 10, 277-285.

Yahdjian L, Sala OE. (2006). Vegetation structure constrains primary production response to water availability in the Patagonian steppe. Ecology 87, 952-962.

Yordanov I, Velikova V, Tsonev T. (2000). Plant responses to drought, acclimation, and stress tolerance. Photosynthetica 38, 171-186.

Zhang L, Gao M, Hu J, Zhang X, Wang K, Ashraf M. (2012). Modulation role of abscisic acid (ABA) on growth, water relations and glycinebetaine metabolism in two maize (Zea mays L.) cultivars under drought stress. Int. J. Mol. Sci. 13, 3189-3202.

Zhang RH, Xue JQ, Pu J, Zhao B, Zhang XH, Zheng YJ, Bu LD. (2011). Effects of drought stress on plant growth and photosynthetic characteristic of maize seedlings. Acta Agron. Sin. 37, 521-528.

Zheng H, Zhang X, Ma W, Song J, Rahman SU, Wang J, Zhang Y. (2017). Morphological and physiological responses to cyclic drought in two contrasting genotypes of Catalpa bungei. 
bioRxiv preprint doi: https://doi.org/10.1101/170258; this version posted July 30, 2017. The copyright holder for this preprint (which was not certified by peer review) is the author/funder, who has granted bioRxiv a license to display the preprint in perpetuity. It is made available under aCC-BY-NC-ND 4.0 International license.

896 Environ. Exp. Bot. 138, 77-87.

897 Zhou GS. (2014). Research perspectives on effect of climate change on China' Agricultural 898 production. Meteorol. Environ. Sci. 38, 80-94.

899

900 
Table 1 Simulated rainfall regimes in the field experiment under a rain-shelter.

\begin{tabular}{|c|c|c|c|c|c|c|}
\hline \multirow[t]{2}{*}{$\begin{array}{l}\text { Growth } \\
\text { stage }\end{array}$} & \multirow[t]{2}{*}{$\begin{array}{c}\text { Irrigation } \\
\text { dates(Month/day) }\end{array}$} & $\begin{array}{c}\mathbf{T}_{1} \\
\text { Irrigating at } \\
\text { every 7-day }\end{array}$ & $\begin{array}{c}\mathbf{T}_{\mathbf{2}} \\
\text { Drought } \\
\text { episode } \\
\text { (27 days) }\end{array}$ & $\begin{array}{c}\mathbf{T}_{\mathbf{3}} \\
\text { Drought } \\
\text { episode } \\
\text { (41 days) }\end{array}$ & $\begin{array}{c}\mathbf{T}_{\mathbf{4}} \\
\text { Drought } \\
\text { episode } \\
\text { (41 days) } \\
\end{array}$ & $\begin{array}{c}\mathbf{T}_{\mathbf{5}} \\
\text { Drought } \\
\text { episode } \\
\text { (34 days) }\end{array}$ \\
\hline & & \multicolumn{5}{|c|}{ Irrigation amount (mm) } \\
\hline \multirow{6}{*}{ V3 V13 } & $5 / 24$ & 8.7 & 8.7 & 8.7 & 8.7 & 8.7 \\
\hline & $5 / 30$ & 0.8 & 0.8 & 0.8 & 0.8 & 0.8 \\
\hline & $6 / 8$ & 10 & 10 & 10 & 10 & 10 \\
\hline & $6 / 15$ & 10 & 10 & 10 & 10 & 10 \\
\hline & $6 / 22$ & 10 & 10 & 10 & 10 & 10 \\
\hline & $6 / 29$ & 24 & 24 & 24 & 24 & 24 \\
\hline \multirow{3}{*}{ V13 VT } & $7 / 6$ & 24 & 0 & 0 & 24 & 24 \\
\hline & $7 / 13$ & 24 & 0 & 0 & 24 & 24 \\
\hline & $7 / 20$ & 25 & 0 & 0 & & 25 \\
\hline \multirow{5}{*}{$\mathrm{VT} \sim \mathrm{R} 4$} & $7 / 27$ & 25 & 25 & 0 & 0 & 0 \\
\hline & $8 / 3$ & 25 & 25 & 0 & 0 & 0 \\
\hline & $8 / 10$ & 25 & 25 & 25 & 0 & 0 \\
\hline & $8 / 17$ & 25 & 25 & 25 & 0 & 0 \\
\hline & $8 / 24$ & 24 & 24 & 24 & 24 & 24 \\
\hline $\begin{array}{l}\text { Entire } \\
\text { period }\end{array}$ & Total precipitation & 260.5 & 187.5 & 137.5 & 135.5 & 160.5 \\
\hline
\end{tabular}

904 25, July (VT, tasseling); 31, July (R1, Silking); 7, August (R2, blistering); 14, August (R3, 905 milking); 29, August (R4, dough), respectively. Red parts indicate the drought episodes. Relative 906 Soil water moisture (0 - 50 cm depth) decreased to a severe water deficit stress level of 30-40\% at 907 the ends of the drought episodes, meanwhile it maintained a normal level of $70-80 \%$ in the control 908 plots or after rewatering. The maize growth stage nomenclature refers to Abendroth et al. (2009), 909 http://lib.dr.iastate.edu/extension_pubs/26. Verified 21 July 2017. 
911 Table 2 A significance list based on ANOVA for the effects and their interactions on the traits

912 from watering, leaf position, and date

\begin{tabular}{cccccccccc}
\hline & SPAD & $A_{\text {sat }}$ & $E$ & $g_{\mathrm{s}}$ & WUE & $q_{\mathrm{P}}$ & $\mathrm{NPQ}$ & $\Phi_{\mathrm{PSII}}$ & $F_{\mathrm{v}}{ }^{\prime} / F_{\mathrm{m}}{ }^{\prime}$ \\
\hline $\mathrm{W}$ & $<0.001$ & $<0.001$ & $<0.001$ & 0.988 & 0.007 & 0.114 & $<0.001$ & 0.215 & 0.946 \\
$\mathrm{LP}$ & $<0.001$ & $<0.001$ & $<0.001$ & 0.589 & $<0.001$ & $<0.001$ & 0.018 & 0.005 & 0.063 \\
$\mathrm{Date}$ & $<0.001$ & $<0.001$ & $<0.001$ & 0.009 & $<0.001$ & $<0.001$ & $<0.001$ & $<0.001$ & $<0.001$ \\
$\mathrm{~W} \times \mathrm{LP}$ & 0.768 & 0.578 & 0.469 & 0.515 & 0.271 & 0.825 & 0.194 & 0.633 & 0.399 \\
$\mathrm{~W} \times \mathrm{D}$ & $<0.001$ & 0.006 & $<0.001$ & 0.324 & $<0.001$ & 0.692 & $<0.001$ & 0.307 & 0.512 \\
$\mathrm{LP} \times \mathrm{D}$ & $<0.001$ & 0.002 & $<0.001$ & 0.014 & 0.454 & $<0.001$ & 0.178 & $<0.001$ & $<0.001$ \\
$\mathrm{~W} \times \mathrm{LP} \times \mathrm{D}$ & $0.156 \mathrm{~ns}$ & $0.963 \mathrm{~ns}$ & $0.939 \mathrm{~ns}$ & $0.946 \mathrm{~ns}$ & $0.452 \mathrm{~ns}$ & $0.692 \mathrm{~ns}$ & $0.990 \mathrm{~ns}$ & $0.850 \mathrm{~ns}$ & $0.635 \mathrm{~ns}$ \\
\hline $\mathrm{N}$ & & & & & & & & &
\end{tabular}

Note: $P$ values are given. ns, no significant difference; $\mathrm{W}, \mathrm{LP}$, and $\mathrm{D}$ denote watering treatment, leaf position, and measurement data, respectively. $\times$, interaction sign; SPAD, relative chlorophyll content; $A_{\text {sat }}$, light-saturated photosynthetic rate; $E$, transpiration rate; $g_{s}$, stomatal conductance; WUE, water use efficiency; $\Phi_{\text {PSII }}$, PSII actual quantum yield; $F_{\mathrm{v}}^{\prime} / F_{\mathrm{m}}{ }^{\prime}$, maximum quantum yield; $q_{\mathrm{P}}$, photochemical quenching; NPQ, non-photochemical quenching. 
Table 3 Effects of drought and rewatering on the plant growth and morphological indicators of maize (2016).

\begin{tabular}{|c|c|c|c|c|c|c|c|c|}
\hline Traits & Treatments & $1 \mathrm{Jul}$ & $14 \mathrm{Jul}$ & $25 \mathrm{Jul}$ & $31 \mathrm{Jul}$ & $7 \mathrm{Aug}$ & 14 Aug & 29 Aug \\
\hline \multirow{5}{*}{ Plant height (m) } & $\mathrm{T}_{1}$ & $1.434 \pm 0.066 \mathrm{a}$ & $2.014 \pm 0.097 \mathrm{a}$ & $2.667 \pm 0.084 a$ & $2.717 \pm 0.119 \mathrm{a}$ & $2.734 \pm 0.134 a$ & $2.729 \pm 0.144 \mathrm{a}$ & $2.717 \pm 0.134 \mathrm{a}$ \\
\hline & $\mathrm{T}_{2}$ & $1.336 \pm 0.057 \mathrm{a}$ & $1.897 \pm 0.051 \mathrm{a}$ & $2.233 \pm 0.093 b$ & $2.240 \pm 0.084 \mathrm{a}$ & $2.232 \pm 0.092 b$ & $2.428 \pm 0.224 \mathrm{a}$ & $2.214 \pm 0.108 \mathrm{a}$ \\
\hline & $\mathrm{T}_{3}$ & $1.476 \pm 0.07 \mathrm{a}$ & $1.897 \pm 0.051 \mathrm{a}$ & $2.233 \pm 0.093 b$ & $2.327 \pm 0.132 \mathrm{a}$ & $2.436 \pm 0.148 a b$ & $2.407 \pm 0.157 \mathrm{a}$ & $2.333 \pm 0.199 \mathrm{a}$ \\
\hline & $\mathrm{T}_{4}$ & $1.477 \pm 0.043 \mathrm{a}$ & $2.014 \pm 0.097 \mathrm{a}$ & $2.670 \pm 0.045 a$ & $2.710 \pm 0.147 \mathrm{a}$ & $2.745 \pm 0.104 a$ & $2.751 \pm 0.110 \mathrm{a}$ & $2.730 \pm 0.099 \mathrm{a}$ \\
\hline & $\mathrm{T}_{5}$ & $1.355 \pm 0.009 \mathrm{a}$ & $2.014 \pm 0.097 \mathrm{a}$ & $2.667 \pm 0.084 a$ & $2.463 \pm 0.224 \mathrm{a}$ & $2.556 \pm 0.212 \mathrm{ab}$ & $2.527 \pm 0.230 \mathrm{a}$ & $2.520 \pm 0.272 \mathrm{a}$ \\
\hline \multirow{5}{*}{$\begin{array}{l}\text { Total leaf area } \\
\left(\mathrm{m}^{2} \text { plant }^{-1}\right)\end{array}$} & $\mathrm{T}_{1}$ & $0.389 \pm 0.025 \mathrm{a}$ & $0.823 \pm 0.035 \mathrm{a}$ & $0.998 \pm 0.018 a$ & $1.049 \pm 0.021 \mathrm{a}$ & $1.037 \pm 0.044 \mathrm{a}$ & $0.974 \pm 0.017 a$ & $0.848 \pm 0.009 a$ \\
\hline & $\mathrm{T}_{2}$ & $0.400 \pm 0.039 \mathrm{a}$ & $0.769 \pm 0.064 \mathrm{a}$ & $0.871 \pm 0.034 b$ & $0.890 \pm 0.065 a$ & $0.930 \pm 0.047 \mathrm{a}$ & $0.809 \pm 0.038 b$ & $0.643 \pm 0.08 b$ \\
\hline & $\mathrm{T}_{3}$ & $0.437 \pm 0.01 \mathrm{a}$ & $0.769 \pm 0.064 \mathrm{a}$ & $0.871 \pm 0.034 b$ & $0.953 \pm 0.097 \mathrm{a}$ & $0.871 \pm 0.054 \mathrm{a}$ & $0.686 \pm 0.042 b$ & $0.692 \pm 0.082 a b$ \\
\hline & $\mathrm{T}_{4}$ & $0.423 \pm 0.038 \mathrm{a}$ & $0.823 \pm 0.035 \mathrm{a}$ & $0.988 \pm 0.023 a$ & $1.025 \pm 0.002 \mathrm{a}$ & $0.974 \pm 0.016 \mathrm{a}$ & $0.768 \pm 0.058 b$ & $0.781 \pm 0.012 a b$ \\
\hline & $\mathrm{T}_{5}$ & $0.363 \pm 0.006 a$ & $0.823 \pm 0.035 \mathrm{a}$ & $0.998 \pm 0.018 a$ & $0.877 \pm 0.078 \mathrm{a}$ & $0.879 \pm 0.067 \mathrm{a}$ & $0.837 \pm 0.07 a b$ & $0.738 \pm 0.043 a b$ \\
\hline \multirow{5}{*}{$\begin{array}{l}\text { Leaf rolling index } \\
\text { (LRI, \%) }\end{array}$} & $\mathrm{T}_{1}$ & $9.801 \pm 0.814 \mathrm{a}$ & $13.031 \pm 1.87 b$ & $7.993 \pm 2.824 b$ & $5.381 \pm 0.285 c$ & $9.712 \pm 1.127 d$ & $9.795 \pm 1.410 \mathrm{c}$ & $12.907 \pm 0.682 \mathrm{a}$ \\
\hline & $\mathrm{T}_{2}$ & $10.143 \pm 0.795 a$ & $19.274 \pm 0.614 a$ & $17.626 \pm 1.356 a$ & $11.702 \pm 2.561 b$ & $12.126 \pm 2.358 \mathrm{~cd}$ & $10.453 \pm 0.910 \mathrm{c}$ & $18.344 \pm 4.505 \mathrm{a}$ \\
\hline & $\mathrm{T}_{3}$ & $11.116 \pm 0.288 \mathrm{a}$ & $19.274 \pm 0.614 a$ & $17.626 \pm 1.356 a$ & $23.194 \pm 1.653 a$ & $26.575 \pm 0.513 a$ & $17.24 \pm 1.212 \mathrm{ab}$ & $18.692 \pm 1.192 \mathrm{a}$ \\
\hline & $\mathrm{T}_{4}$ & $9.691 \pm 1.278 \mathrm{a}$ & $13.031 \pm 1.87 b$ & $9.594 \pm 1.546 b$ & $10.163 \pm 0.466 b$ & $16.867 \pm 0.658 b$ & $21.926 \pm 2.889 a$ & $18.93 \pm 3.082 \mathrm{a}$ \\
\hline & $\mathrm{T}_{5}$ & $11.322 \pm 1.539 \mathrm{a}$ & $13.031 \pm 1.87 b$ & $7.993 \pm 2.824 b$ & $7.336 \pm 0.257 b c$ & $15.059 \pm 0.874 b c$ & $14.641 \pm 0.925 b c$ & $12.608 \pm 2.55 \mathrm{a}$ \\
\hline \multirow{5}{*}{$\begin{array}{l}\text { Leaf erection index } \\
\text { (LEI, \%) }\end{array}$} & $\mathrm{T}_{1}$ & $71.734 \pm 2.621 \mathrm{a}$ & $81.218 \pm 5.921 \mathrm{a}$ & $87.103 \pm 2.10 \mathrm{a}$ & $71.813 \pm 7.855 \mathrm{a}$ & $70.960 \pm 2.811 \mathrm{a}$ & $59.500 \pm 4.481 \mathrm{a}$ & $79.330 \pm 7.217 a$ \\
\hline & $\mathrm{T}_{2}$ & $73.885 \pm 0.901 \mathrm{a}$ & $81.710 \pm 6.650 \mathrm{a}$ & $92.412 \pm 1.10 \mathrm{a}$ & $59.130 \pm 6.364 \mathrm{a}$ & $65.779 \pm 1.005 \mathrm{a}$ & $54.834 \pm 5.317 \mathrm{a}$ & $65.922 \pm 1.196 a$ \\
\hline & $\mathrm{T}_{3}$ & $70.300 \pm 1.434 \mathrm{a}$ & $81.710 \pm 6.650 \mathrm{a}$ & $92.412 \pm 1.10 \mathrm{a}$ & $56.537 \pm 3.256 \mathrm{a}$ & $61.011 \pm 4.763 \mathrm{a}$ & $50.771 \pm 5.036 \mathrm{a}$ & $68.788 \pm 3.498 a$ \\
\hline & $\mathrm{T}_{4}$ & $73.822 \pm 2.055 \mathrm{a}$ & $81.218 \pm 5.921 \mathrm{a}$ & $79.918 \pm 10.07 \mathrm{a}$ & $65.282 \pm 7.415 \mathrm{a}$ & $64.864 \pm 5.571 \mathrm{a}$ & $50.230 \pm 1.623 \mathrm{a}$ & $52.139 \pm 3.120 b$ \\
\hline & $\mathrm{T}_{5}$ & $71.160 \pm 6.133 a$ & $81.218 \pm 5.921 \mathrm{a}$ & $87.103 \pm 2.10 \mathrm{a}$ & $59.149 \pm 8.36 \mathrm{a}$ & $56.684 \pm 7.818 \mathrm{a}$ & $46.903 \pm 3.308 \mathrm{a}$ & $49.341 \pm 4.209 \mathrm{~b}$ \\
\hline \multirow{5}{*}{$\begin{array}{l}\text { Leaf bend degree } \\
\left(\mathrm{LBD},{ }^{\circ}\right)\end{array}$} & $\mathrm{T}_{1}$ & $37.417 \pm 1.856 \mathrm{a}$ & $16.750 \pm 4.116 \mathrm{a}$ & $9.333 \pm 1.764 \mathrm{a}$ & $36.222 \pm 4.283 \mathrm{c}$ & $53.567 \pm 6.19 a$ & $81.417 \pm 9.419 a$ & $59.983 \pm 20.037 \mathrm{a}$ \\
\hline & $\mathrm{T}_{2}$ & $33.000 \pm 1.953 \mathrm{a}$ & $16.000 \pm 6.948 \mathrm{a}$ & $11.783 \pm 3.537 \mathrm{a}$ & $50.694 \pm 5.022 \mathrm{ab}$ & $41.833 \pm 2.485 \mathrm{a}$ & $69.167 \pm 5.988 \mathrm{a}$ & $44.233 \pm 13.638 \mathrm{a}$ \\
\hline & $\mathrm{T}_{3}$ & $39.667 \pm 5.516 \mathrm{a}$ & $16.000 \pm 6.948 \mathrm{a}$ & $11.783 \pm 3.537 \mathrm{a}$ & $55.833 \pm 4.757 a$ & $37.083 \pm 7.045 \mathrm{a}$ & $71.117 \pm 7.148 \mathrm{a}$ & $49.583 \pm 18.112 \mathrm{a}$ \\
\hline & $\mathrm{T}_{4}$ & $33.917 \pm 1.609 a$ & $16.750 \pm 4.116 \mathrm{a}$ & $13.833 \pm 2.167 \mathrm{a}$ & $31.722 \pm 3.692 c$ & $45.167 \pm 6.749 \mathrm{a}$ & $65.278 \pm 8.084 a$ & $83.694 \pm 11.916 a$ \\
\hline & $\mathrm{T}_{5}$ & $35.750 \pm 3.527 \mathrm{a}$ & $16.750 \pm 4.116 \mathrm{a}$ & $9.333 \pm 1.764 \mathrm{a}$ & $37.944 \pm 1.811 b c$ & $50.733 \pm 2.709 a$ & $60.833 \pm 6.194 \mathrm{a}$ & $55.361 \pm 4.835 \mathrm{a}$ \\
\hline
\end{tabular}

Note: $\mathrm{T}_{1}, \mathrm{~T}_{2}, \mathrm{~T}_{3}, \mathrm{~T}_{4}$, and $\mathrm{T}_{5}$ denote Control, withholding water during jointing-tasseling, jointing-anthesis, tasseling-milking, and silking-milking, with $260,188,138,136$, and $161 \mathrm{~mm}$ irrigation amount in entire development, respectively. Different little-letters with mean data indicate significant differences between the five watering treatments (bold parts, $\mathrm{n}=3-5$ ). 
Table 4 Correlation coefficients between the functional and morphological traits of upper leaves

\begin{tabular}{|c|c|c|c|c|c|c|c|c|c|c|c|}
\hline & SPAD & $A_{\text {sat }}$ & $E$ & $g_{\mathrm{s}}$ & WUE & $\Phi_{\text {PSII }}$ & $F_{\mathrm{v}}^{\prime} / F_{\mathrm{m}}^{\prime}$ & Plant height & Plant leaf area & LRI & LEI \\
\hline$A_{\text {sat }}$ & $0.546^{* *}$ & & & & & & & & & & \\
\hline E & $0.498 * *$ & $0.813^{* *}$ & & & & & & & & & \\
\hline$g_{\mathrm{s}}$ & $0.427 * *$ & $0.845 * *$ & $0.816 * *$ & & & & & & & & \\
\hline WUE & $0.304 *$ & $0.479 * *$ & 0.042 & 0.186 & & & & & & & \\
\hline$\Phi_{\text {PSII }}$ & -0.152 & -0.184 & -0.039 & -0.143 & -0.206 & & & & & & \\
\hline$F_{\mathrm{v}}{ }^{\prime} / F_{\mathrm{m}}{ }^{\prime}$ & -0.111 & -0.045 & 0.045 & -0.049 & -0.119 & $0.911 * *$ & & & & & \\
\hline Pant height & -0.232 & $-0.391 * *$ & -0.168 & $-0.316 * *$ & $-0.344^{* *}$ & -0.036 & -0.02 & & & & \\
\hline Plant leaf area & -0.021 & -0.211 & -0.035 & -0.222 & -0.238 & -0.015 & 0.021 & $0.854 * *$ & & & \\
\hline LRI & $-0.436 * *$ & $-0.506 * *$ & $-0.449 * *$ & $-0.422 * *$ & -0.204 & 0.014 & -0.039 & 0.18 & 0.094 & & \\
\hline LEI & 0.145 & $0.328 * *$ & 0.217 & $0.264 *$ & 0.227 & -0.166 & -0.025 & $-0.298 *$ & -0.185 & -0.211 & \\
\hline LBD & $-0.264 * *$ & $-0.383 * *$ & -0.232 & $-0.310 *$ & $-0.279 *$ & 0.119 & 0.007 & $0.389 * *$ & 0.139 & 0.151 & $-0.460 * *$ \\
\hline
\end{tabular}

$* P<0.05, * * P<0.01$ represent significant differences. LRI, leaf rolling index; LEI, leaf erection index; LBD, leaf bend degree. Others see table 2. 
(a)

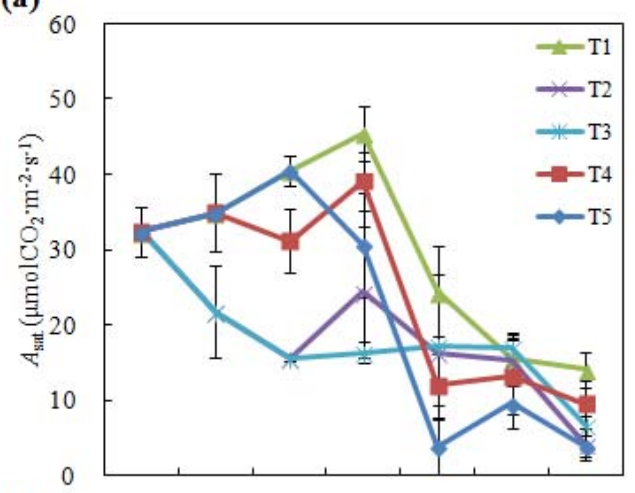

(c)

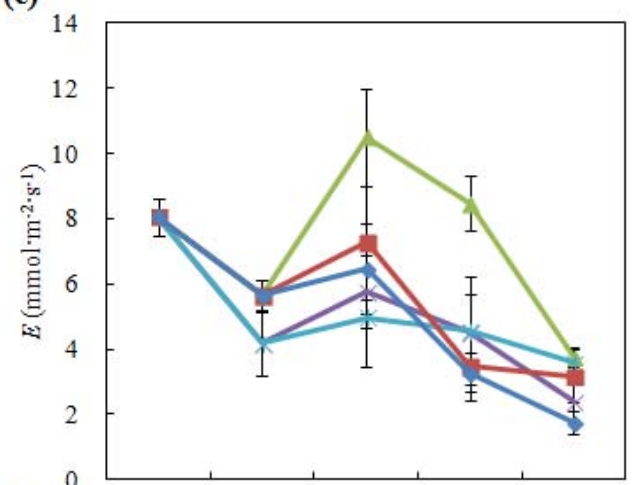

(e)

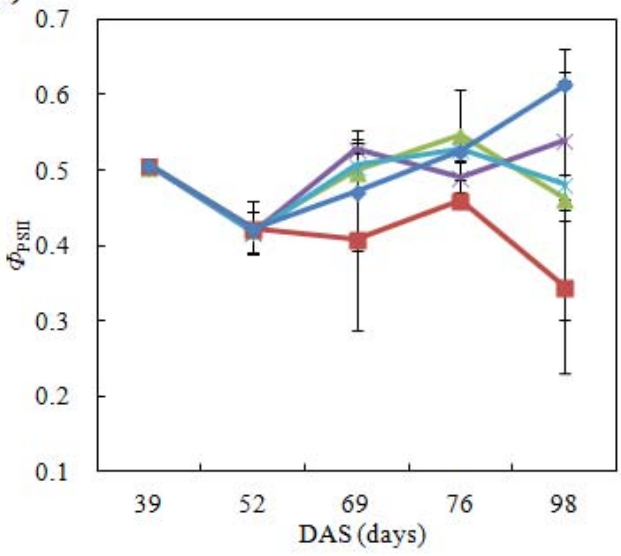

(b)

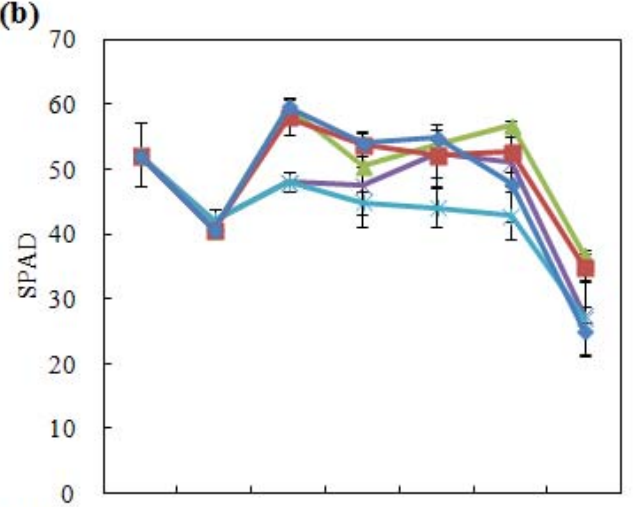

(d)

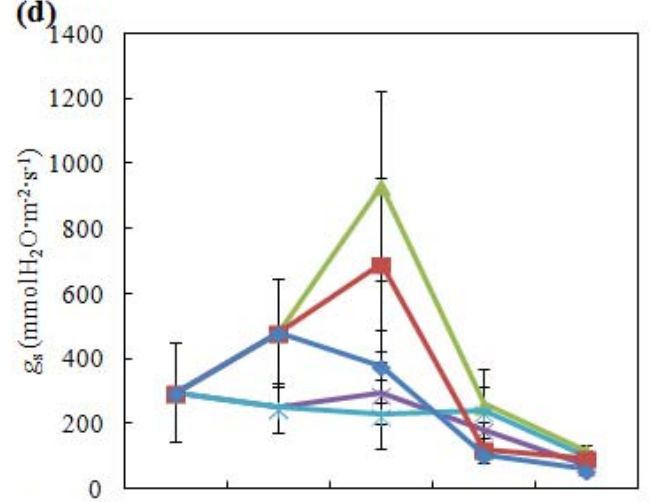

(f)

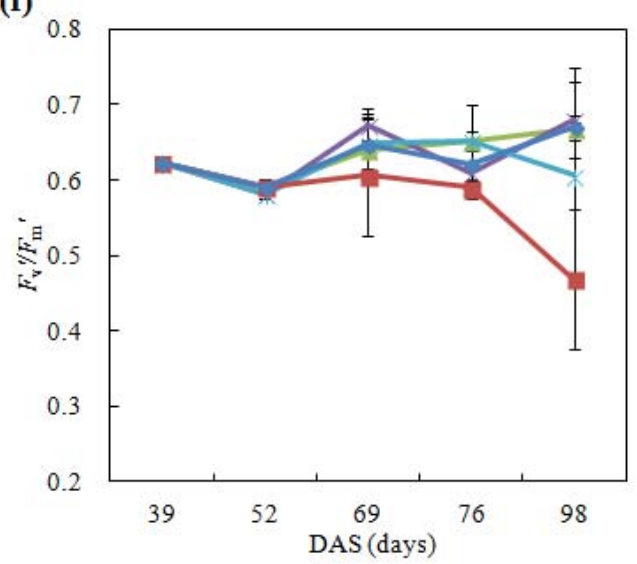

Figure 1. Effects of drought episode and rewatering on photosynthetic physiological processes in upper leaves.

Notes: DAS, days after sowing; $A_{\text {sat }}$, light-saturated photosynthetic rate; SPAD, relative chlorophyll contents; $g_{\mathrm{s}}$, stomatal conductance; $E$, transpiration rate; $\Phi_{\mathrm{PSII}}$, PSII actual quantum yield; $F_{\mathrm{v}}{ }^{\prime} / F_{\mathrm{m}}{ }^{\prime}$, maximum quantum yield. T1, T2, T3, T4, and T5 denote Control, withholding water during jointing-tasseling, jointing-anthesis, tasseling-milking, and silking-milking, with 260, 188, 138,136 , and $161 \mathrm{~mm}$ irrigation amount in entire plant development, respectively. 
(a)

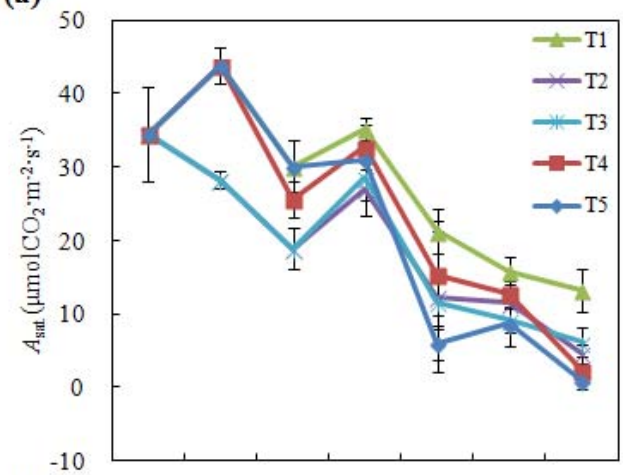

(c)

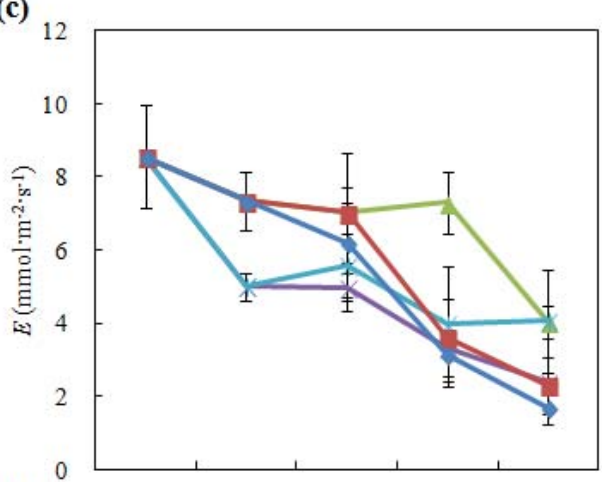

(e)

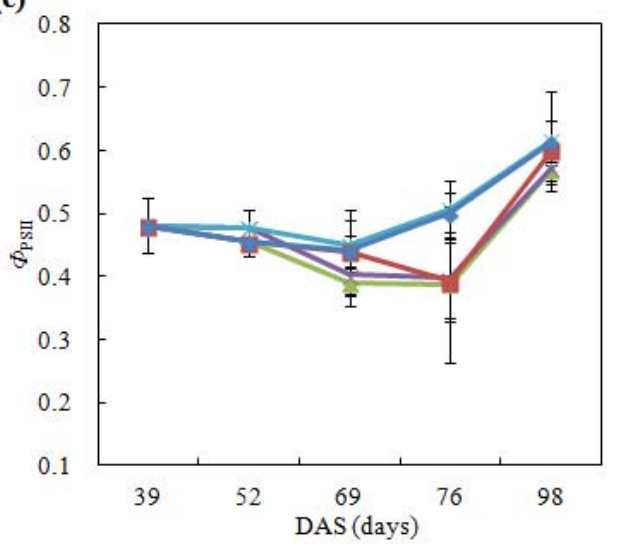

(b)

(d)
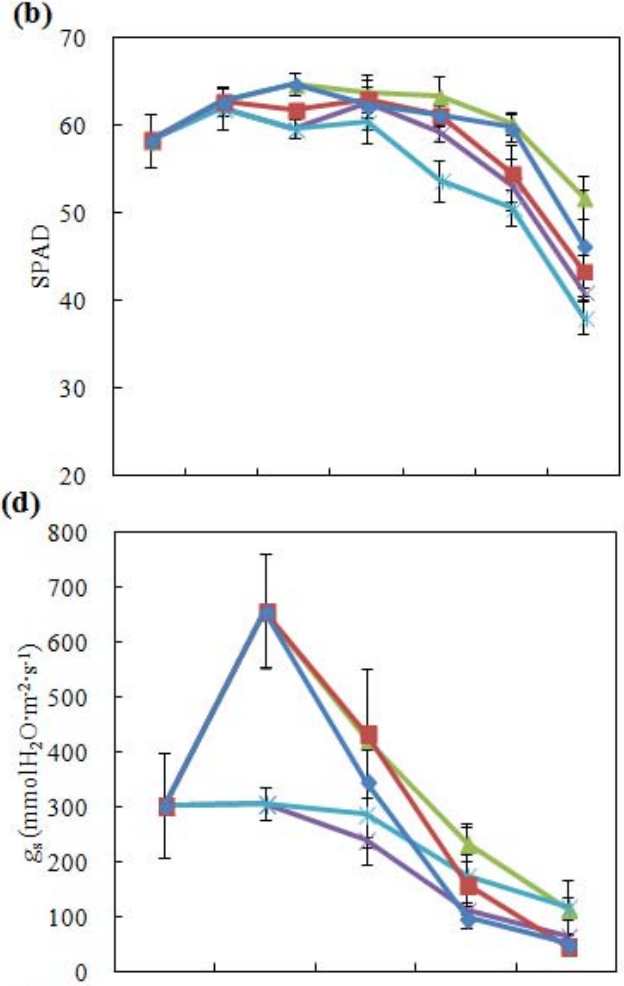

(f)

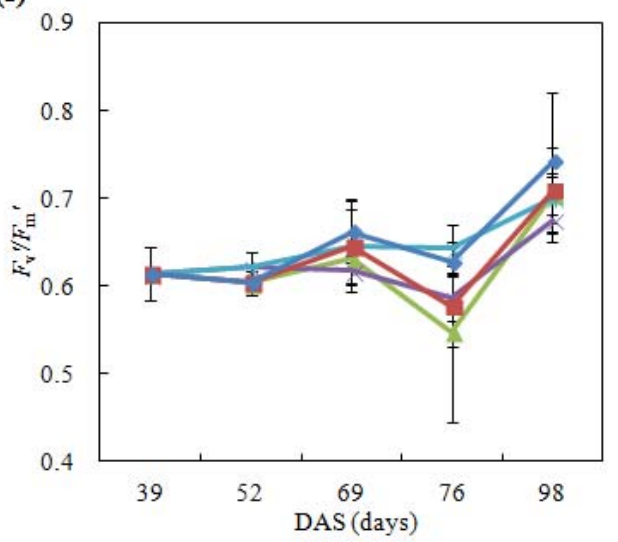

Figure 2. Effects of drought episode and rewatering on photosynthetic physiological processes in middle leaves.

Notes: DAS, days after sowing; $A_{\text {sat }}$, light-saturated photosynthetic rate; SPAD, relative chlorophyll contents; $g_{\mathrm{s}}$, stomatal conductance; $E$, transpiration rate; $\Phi_{\mathrm{PSII}}$, PSII actual quantum yield; $F_{\mathrm{v}}{ }^{\prime} / F_{\mathrm{m}}{ }^{\prime}$, maximum quantum yield. T1, T2, T3, T4, and T5 denote Control, withholding water during jointing-tasseling, jointing-anthesis, tasseling-milking, and silking-milking, with 260, 188, 138, 136, and $161 \mathrm{~mm}$ irrigation amount in entire plant development, respectively 
(a)

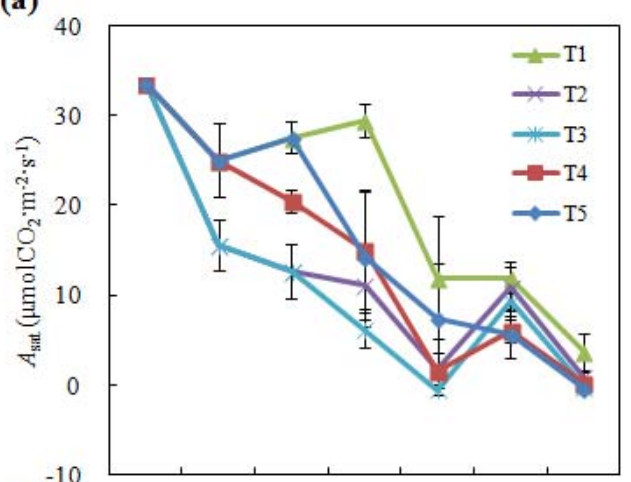

(c)

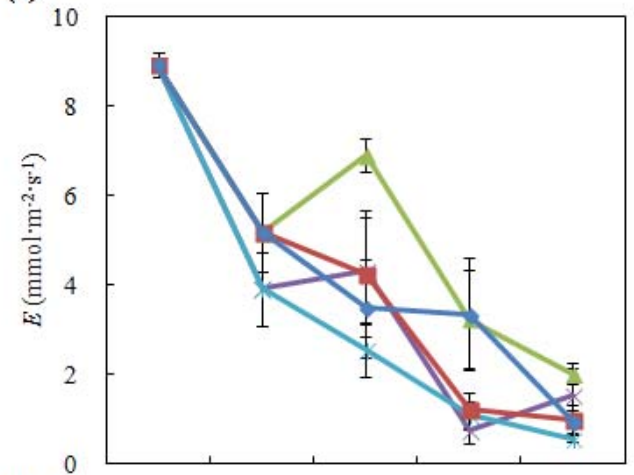

(e)

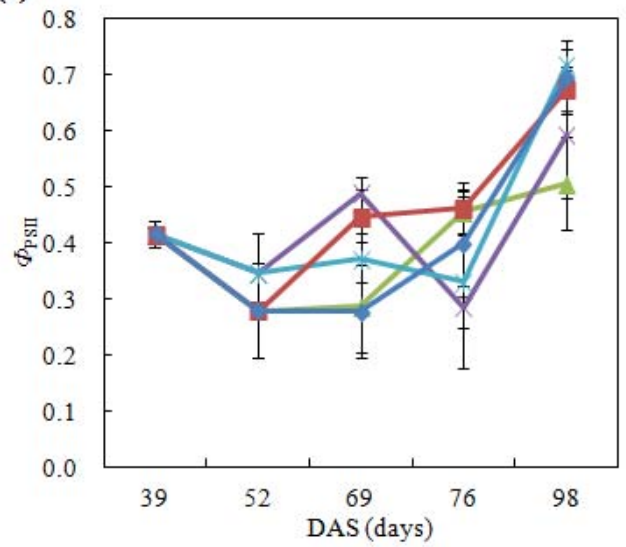

(b)

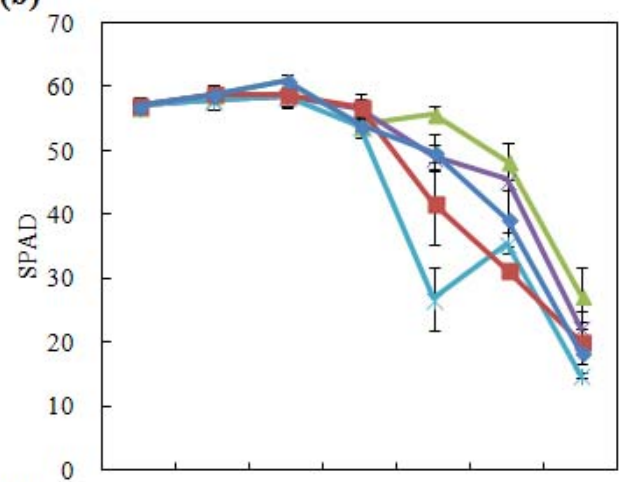

(d)

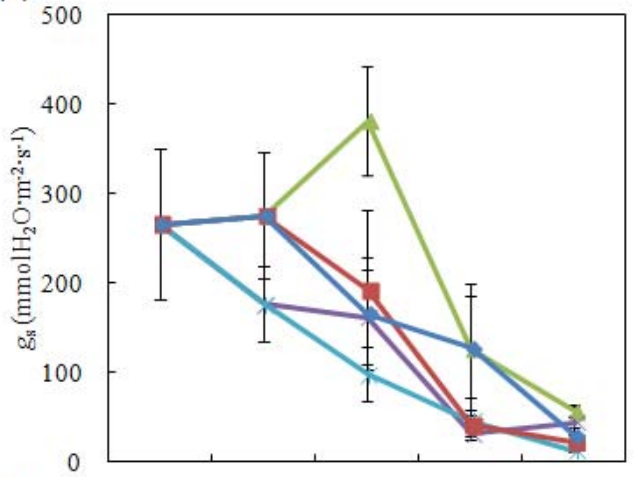

(f)

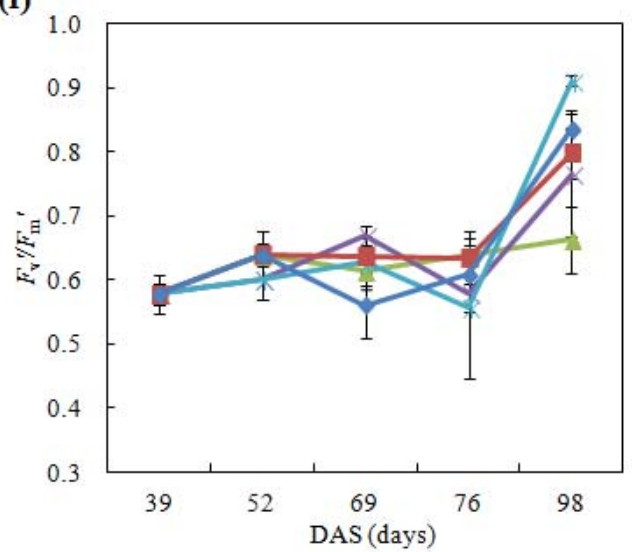

Figure 3. Effects of drought episode and rewatering on photosynthetic physiological processes in bottom leaves.

Notes: DAS, days after sowing; $A_{\text {sat }}$, light-saturated photosynthetic rate; SPAD, relative chlorophyll contents; $g_{\mathrm{s}}$, stomatal conductance; $E$, transpiration rate; $\Phi_{\mathrm{PSII}}$. PSII actual quantum yield; $F_{\mathrm{v}}{ }^{\prime} / F_{\mathrm{m}}{ }^{\prime}$, maximum quantum yield. T1, T2, T3, T4, and T5 denote Control, withholding water during jointing-tasseling, jointing-anthesis, tasseling-milking, and silking-milking, with 260, 188, 138, 136, and $161 \mathrm{~mm}$ irrigation amount in entire plant development, respectively. 
(a)

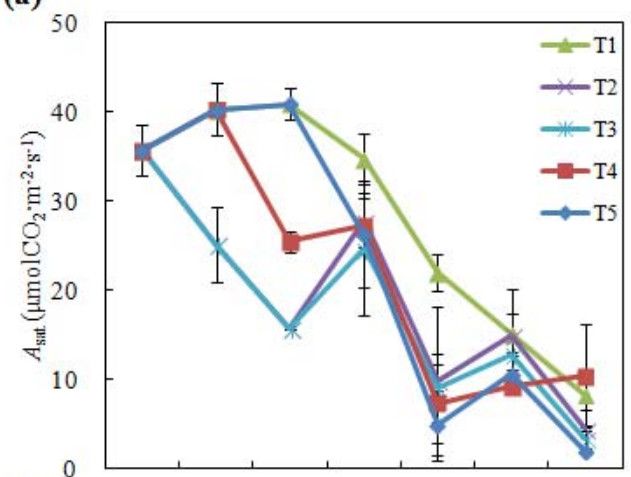

(c)

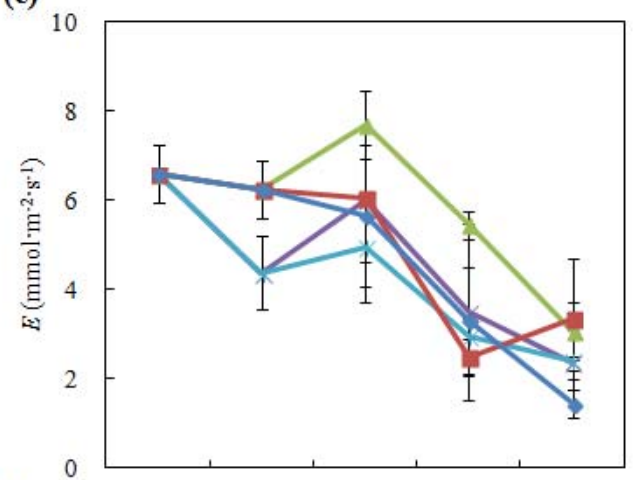

(e)

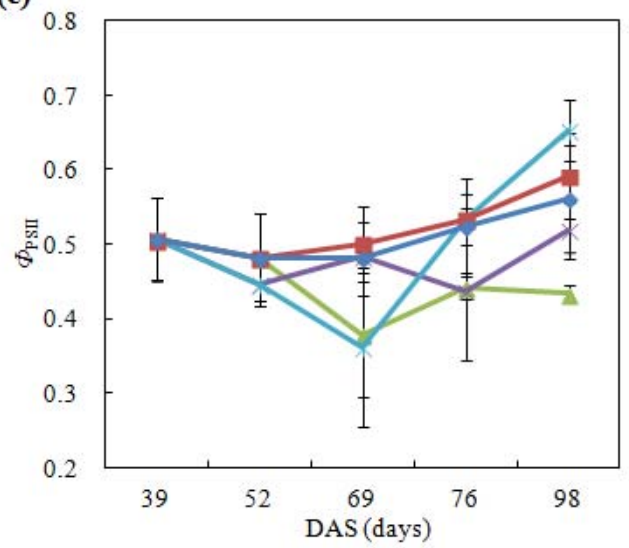

(b)

(d)
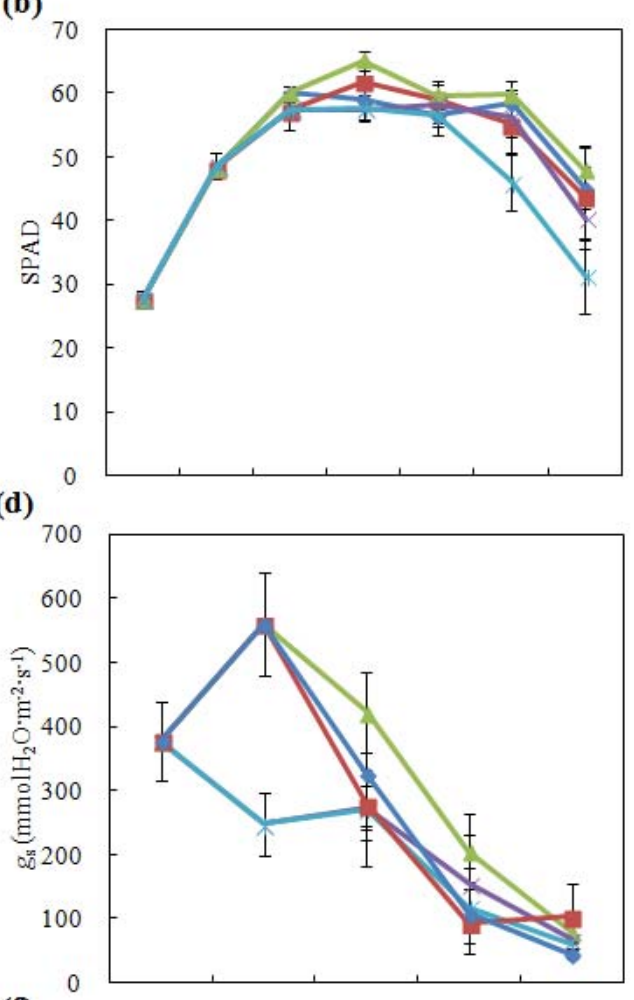

(f)

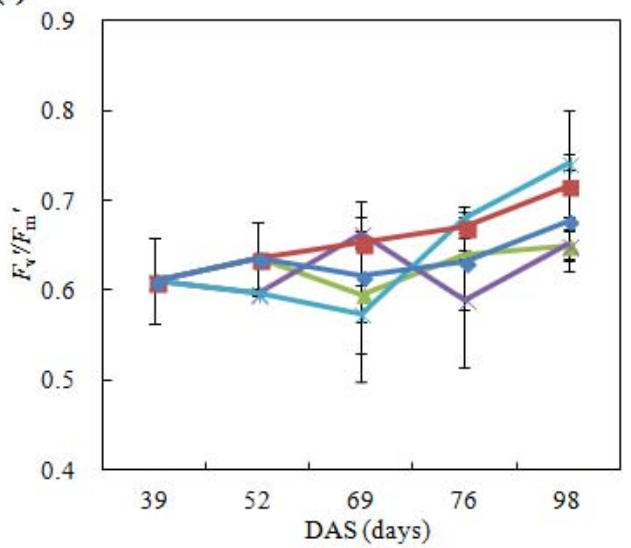

Figure 4. Photosynthetic physiological changes and the responses to drought episode and rewatering in the tagged leaves.

Notes: DAS, days after sowing; $A_{\text {sat }}$, light-saturated photosynthetic rate; SPAD, relative chlorophyll contents; $g_{\mathrm{s}}$, stomatal conductance; $E$, transpiration rate; $\Phi_{\mathrm{PSII}}$, PSII actual quantum yield; $F_{\mathrm{v}}{ }^{\prime} / F_{\mathrm{m}}{ }^{\prime}$, maximum quantum yield. $\mathrm{T}_{1}, \mathrm{~T}_{2}, \mathrm{~T}_{3}, \mathrm{~T}_{4}$, and $\mathrm{T}_{5}$ denote Control, withholding water during jointing-tasseling, jointing-anthesis, tasseling-milking, and silking-milking, with 260, 188, 138, 136, and $161 \mathrm{~mm}$ irrigation amount in entire plant development, respectively. 

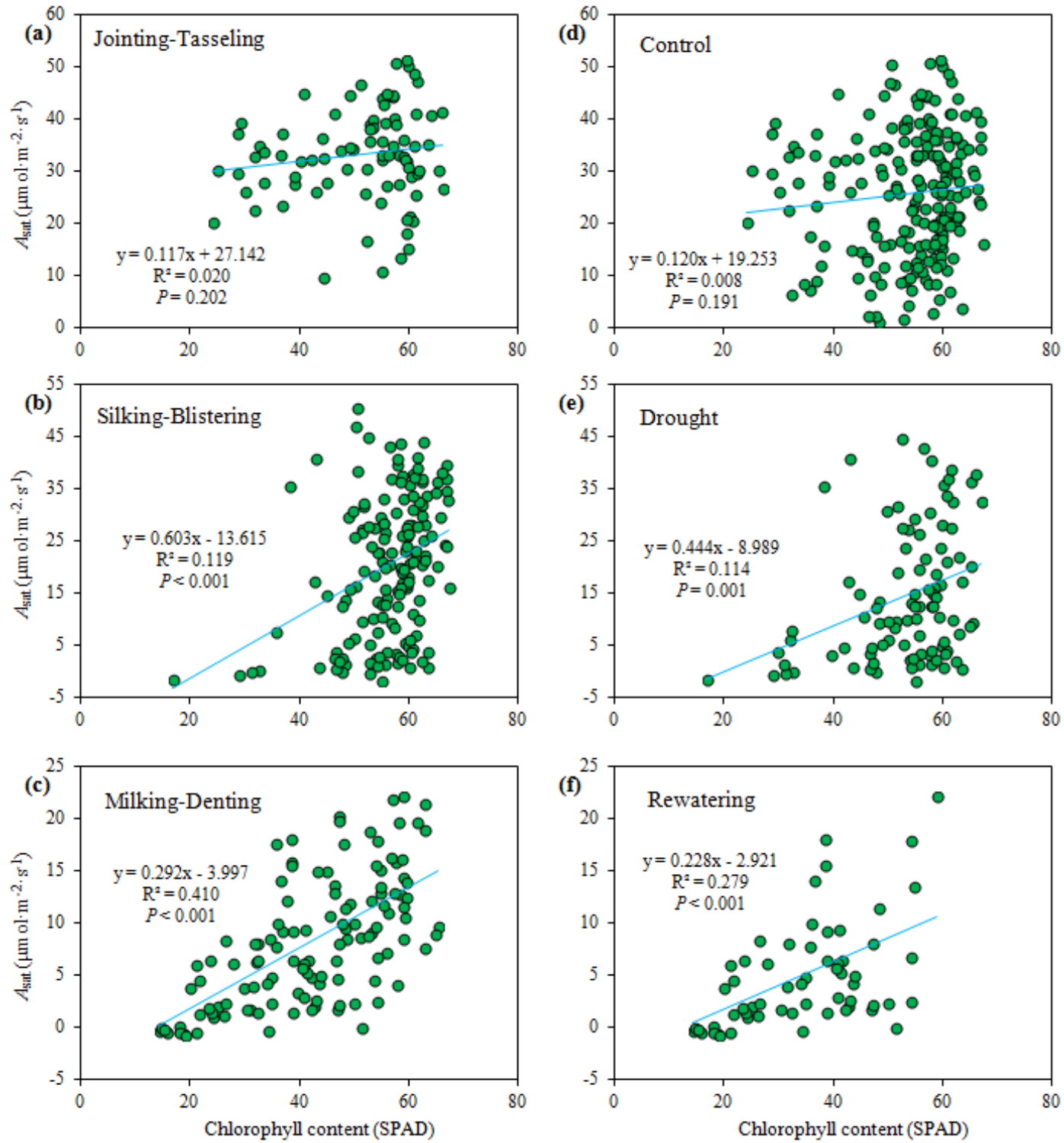

Figure 5 Effects of drought, rewatering, and plant developmental stages on relationships between light-saturated photosynthetic rate $\left(A_{\text {sat }}\right)$ and relative chlorophyll content (SPAD readings). 

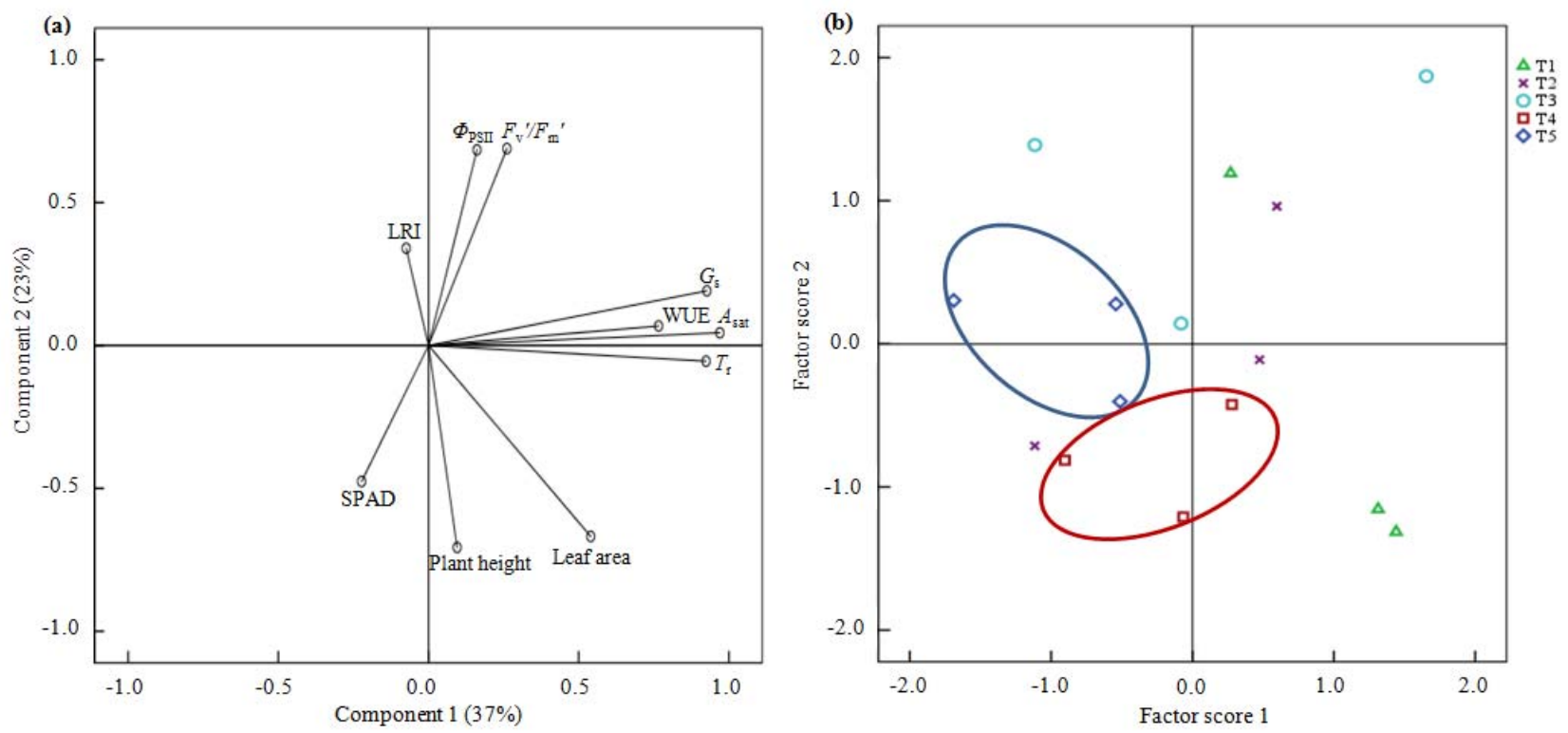

Figure 6 Principal component analysis on leaf functional and morphological traits and the effects of watering treatments at silking stage.

Notes: LRI, leaf-rolling index; WUE, water use efficiency; red ellipse is for $\mathrm{T}_{4}$ treatment, while blue one is for $\mathrm{T}_{5}$ treatment. For others see Fig. 1 and table 3. 